\title{
ADMINISTRATIVE SUBSTANCE
}

\author{
CASS R. SUnSTEIN*
}

I. Introduction .................................. 607

II. Regulatory Rationales.......................... 611

A. Notes on First Principles ..................... 611

1. Liberal Republicanism ...................... 612

2. The New Deal Reformation ................... 616

B. (Some of) The Limits of Markets ................ 618

III. Regulatory Successes and Failures................. 622

A. Successes ................................ 622

B. Failures .................................. 625

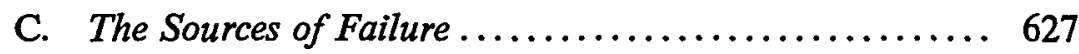

IV. Regulating With Incentives....................... 631

A. General Lessons ........................... 631

B. Particulars ............................... 634

1. Market-Based Incentives in the Environmental Area .................................... 634

a. Emissions trading programs ............... 634

b. Taxation ............................. 637

c. Deposits ............................ 639

2. Market-Based Incentives for Occupational Safety and Health .............................. 640

3. Market-Based Incentives in Other Areas .......... 641

V. Lessons for the Judiciary ......................... 642

VI. Conclusion ................................. 644

\section{INTRODUCTION}

For the last generation, work in administrative law has generally followed the path niarked out by Kenneth Culp Davis ${ }^{1}$ and Louis Jaffe. ${ }^{2}$ Judicial review of administrative action has been the principal focus of

* Karl N. Llewellyn Professor of Jurisprudence, University of Chicago Law School; Professor of Political Science, University of Chicago. Some of the arguments in this Article also appear, in different form, in C. SUnstein, AfTER THE Rights Revolution: RECONCEIVING THE REgulATORY STATE (1990).

1. See K. Davis, Administrative Law Treatise (1958).

2. See L. Jaffe, Judicial Control of Administrative Action (1965). 
the subject, ${ }^{3}$ and the control of adininistrative discretion is its principal goal. ${ }^{4}$ The central concern of this scholarship has been the development, through judge-made law, of procedural rules to discipline the exercise of power by bureaucrats.

These topics are of course extremely important. One cannot obtain a complete understanding of the American admimistrative state without an appreciation of the actual and potential contributions of judicial review. For too long, however, those who study and teach the subject have been unduly preoccupied with the role of the courts and with the question of administrative procedure. More than a half-century after the New Deal, the legal culture contmues to lack a solid understanding of the substantive purposes of regulatory programs, the pathologies to which these programs are subject, the forces that bring about those pathologies, and the consequences of regulation for the real world.

The point is confirmed by the fact that many views on regulation tend to operate as articles of faith. Some have a general sense that regulation has failed; others have a general sense that markets are inadequate and that regulatory controls are usually the solution. ${ }^{5}$ But the particulars of regulatory performance over the last generation-the questions about underlying values and commitments, questions aimed at discerning what works and what does not-have yet to become a standard part of the repertoire of those who teach and practice administrative law.

A study of these aspects of governance should be a principal goal of administrative law in the future. Such a study would generate facts and ideas of primary interest to legislators and administrators-the principal architects of admimistrative law. Of course, it would be surprising if an understanding of regulatory goals and performance did not ultinately affect the practice of judicial review. The effect on the judiciary should, however, be a secondary concern in hight of the inevitably derivative and

3. There are prominent exceptions. See, e.g., S. BREYER, REGULATION AND ITS REFORM (1982) (constructing a framework for the analysis, evaluation, and development of regulatory programs); Rose-Ackerman, Progressive Law and Economics-And the New Administrative Law, 98 YALE L.J. 341 (1988) (urging broader perspective based on political science and economics). Christopher Edley's recent book helpfully focuses on the question of improved regulation rather than control of discretion; but it too is perhaps unduly preoccupied with the judiciary. See C. EDLEY, Administrative Law: Rethinking Judicial Control of Bureaucracy (1990).

4. A classic work in political science also focuses on control of administrative discretion. See T. LOW, THE END of LIBERALISM (2d ed. 1979). It is not at all clear, however, that administrative agencies perform better when their administrators are deprived of discretion; the absence of solid evidence to this effect makes the preoccupation with discretion particularly puzzling.

5. In an important sense, this dichotomy is extremely misleading. Markets themselvcs depend on legal rules for their existence, and those rules are inevitably regulatory. I use these terms to conform to common usage. 
partial (which is not to say unimportant) role of the courts in administrative law. ${ }^{6}$

I approach some of these questions by exploring the general problem of so-called "social" regulation, principally in the areas of health, safety, broadcasting, discrimination, and the environment. ${ }^{7}$ The purpose of the discussion is to shift the focus away from procedure and instead to obtain a preliminary sense of admimistrative substance-an area in which, I suggest, we should predict large eventual gains in the study of admimistrative law. I propose a shift not only from procedure to substance, ${ }^{8}$ but also from courts to legislators and admimistrators as the major audience of legal work on administration. I also set forth some general principles by which to operate regulatory systems to control pollution, occupational risk, discrimination, and insufficient quality and diversity in broadcasting. 9

In the last decade, it has become fashionable to decry the regulatory system that has grown up in response to the consumer, labor, anti-discrimination, and environmental movements of the 1930s, 1960s, and 1970s. Under one quite prominent view, government regulation in these areas is often indefensible in principle--because it amounts to unjustified paternalism or public meddhing in private affairs-and is, in any case, intolerable in practice because it predictably makes things worse rather than better. ${ }^{10}$

But this view is myopic. A number of solid arguments justify regulation, and those argnments are not paternalistic at all. ${ }^{11}$ Moreover, social regulation has not always failed: it has protected endangered species,

6. See infra notes $137-50$ and accompanying text.

7. I do not discuss cconomic regulation, which raises a distinctive set of concerns.

8. The effort to move the study of administrative law in this direction is not an entirely new theme. See, e.g., S. BREYer \& R. STEWART, ADMINISTRATIVE LAW AND REgulatoRy Policy 910 (2d ed. 1985) ("We have selected a range of examples designed to introduce students to the substance of 'economic regulation'... because such examples often will illustrate the interaction of 'substance' and 'procedure' that lead a court or an agency to reach a particular result."); S. BREYER, supra note 3, at 341-68 (discussing regulatory substance); J. MASHAW \& D. HARFST, THE STRUGGLE FOR AUTO SAFETY (1990) (analyzing history of auto regulation); G. RoBINSON, E. GELLHORN \& H. Bruff, The ADministrative Process 3-4 (3d ed. 1986) (calling for study of substantive regulatory law).

9. See infra notes $98-136$ and accompanying text.

10. See R. Epstein, Takings: Private Property and the Power of Eminent Domain (1985) (challenging post-New Deal regulation); Posner, The Social Costs of Monopoly and Regulation, in Chicago Studies in Political Economy 279 (G. Stigler ed. 1988) (assessing the effects and aggregate social costs of intervention and public regulation); Williams, Background Norms in the Regulatory State, 58 U. CHI. L. REV. 419, 427-30 (1991) (critically discussing favorable assessment of government intervention).

11. The term "paternalism" may itself be misleading. See Sunstein, Preferences and Politics, 20 Phil. \& PuB. AfF. 3 (1991). 
reduced discrimination, helped clean up the air and water, and saved many thousands of lives. ${ }^{12}$ To be sure, there have been failures, some of thein extreinely serious. ${ }^{13}$ But the failures coine in identifiable patterns, and they can be avoided in the future. The lessons derived from the failures should point regulators in new directions-not toward an exclusive reliance on private markets or toward enthusiasm for laissez-faire, but rather toward strategies that will incorporate an understanding of market forces, promote the democratic character of modern government, and increase international coinpetitiveness while ininimizing undesirable side-effects and reducing regulatory costs.

This Article proceeds in four stages. Part II outlines soine of the arguinents in support of an aggressive regulatory state in the areas of health, safety, civil rights, broadcasting, and environmental protection. These arguments draw on some of the principles that are associated not only with the New Deal, but also with the liberal republicanism that has characterized American public law since its inception.

Part III describes soine of the successes and failures of social regulation, with special einphasis on the reasons for failure. My goals are both to debunk the myth of regulatory failure and to show that the programs that have performed poorly have done so along predictable hines, principally because of the incentives they have created and because of the ways in which they have coinproinised both deinocratic and economic goals.

Part IV outlines new regulatory strategies by which we inight increase decentralization, respect for private autonomy, cost-effectiveness, and flexibility in social regulation. Through this discussion, I seek above all to demonstrate that the goals of economic efficiency and of a wellfunctioning democracy can be entirely coinpatible, indeed inutually reinforcing, across a broad spectruin of regulatory programs. Disclosure and information-producing strategies-strongly favored on econounic grounds-also promote the democratic goals of accountability and political self-determination. Econoinic incentives diminish the power of special interests and ensure that the democratic process focuses on the central question-how inuch regulation at what cost. Decentralization proinotes de1nocratic goals in both private and public spheres. These ideas can be profitably applied to the regulation of labor, the environment, and the broadcasting industry.

Part $\mathrm{V}$ briefly describes how an understanding of regulatory aspiration and regulatory performance inight affect judicial review. In this discussion, I set forth principles of statutory interpretation that may be used

12. See infra notes $62-76$ and accompanying text.

13. See infra notes $77-84$ and accompanying text. 
by courts to reinforce the virtues and minimize the vices of the regulatory state.

\section{Regulatory Rationales}

\section{A. Notes on First Principles}

Administrative law is peculiarly concerned with the distribution of social benefits and burdens in such important areas as social security, taxation, the environment, occupational safety and health, einployment, nuclear power, energy, and national defense. Large substantive debates will inevitably lurk behind even apparently mundane doctrinal controversies.

For this reason, any approach to administrative law ultimately rests on quite general substantive choices. Consider, for example, the claim for a presumption against judicial review of administrative inaction. ${ }^{14}$ Often this claim is defended by reference to purely institutional concerns. ${ }^{15}$ In fact, however, the presumption against judicial review of administrative action steins in large part from a substantive (and highly contested) view that courts should more seriously scrutinize "regulation" than "failure to regulate."16 This view implies that courts should be more hospitable to an agency's refusal to impleinent congressional programs than to its zealousness in the enforcennent process.

Because administrative law inevitably involves substantive choices, the following discussion will depend on soine controversial claims about the foundations of American administrative law. I cannot defend these claims at any length. Instead, I propose to explain what they are, to provide a sense of their historical roots, and to show how they draw from a wide range of ideas that might seem contradictory at first glance. The two foundations with which I am concerned are, first, the liberal repubhcanism that has characterized American public law since the founding period, and, second, the New Deal reformation of the constitutional sys-

14. See, e.g., Heckler v. Chaney, 470 U.S. $821,825-28,837-38$ (1985) (holding that a Food and Drug Administration's decision not to take requested enforcement action was not subject to judicial review).

15. See Williams, The Roots of Deference (Book Review), 100 YALE L.J. 103 (1991) (reviewing C. Edley, Administrative Law: Rethinking Judicial Control of Bureaucracy (1990)) (arguing that the institutional features of federal courts compel judicial deference on issues of resource allocation).

16. The quotation marks are necessary because regulation is in fact always present, in the form of the common law of property, contract, and tort. The failure of a federal regnlatory agency to take action does not leave things to the play of free or voluntary forces, but instead gives rise to another (perhaps more just and efficient) regulatory system. This was a prominent theme in the New Deal era. 
tem, which played such a major role in the inauguration of the administrative state as we know it. ${ }^{17}$

1. Liberal Republicanism. Liberal republicanism embodies several commitments that are designed to be "important in the world."18 Predictably, then, reformers in areas as diverse as labor, the environment, electoral representation, political restructuring, broadcasting, and antidiscrimination law have long imvoked the commitments of liberal republicanism in inaking concrete suggestions for change.

Among the principles of liberal republicanism, the most important is the belief in political deliberation. ${ }^{19}$ In American public law, political outcomes should not merely reflect the aggregated self-interest of wellorganized groups, nor slould they protect only antecedent or prepolitical private rights. ${ }^{20}$ Instead, political outcomes should be produced by an extended process of deliberation and discussion, in which new information and new perspectives are brought to bear.

17. In setting forth the principles of tiberal republicanism, I largely summarize the discussion in Sunstein, Beyond the Republican Revival, 97 YALE L.J. 1539, 1547-58 (1988). In this discussion, liberalism refers to an approach to politics that emphasizes individual freedom and democratic selfgovernment, rather than to the consensus among self-styled "liberals" from 1960 to the present. In the same vein, republicanism refers to a theory of politics that values collective self-determination, political equality, and deliberation, rather than to the views of self-styled "republicans" of the last generation.

In the American context, liberalism and republicanism cannot be sharply distinguished. Efforts to oppose them transform each position into something that reasonable people would find hard to defend-making liberalism, for example, into a commitment to unbridled interest-group pluralism, and republicanism into a wholesale rejection of rights.

18. Edley, The Governance Crisis, Legal Theory, and Political Ideology, 1991 Duke L.J. 561, 594. Professor Edley expresses concern that the "republican revival ... seems trapped in a familiar legal liberalism. ... [I]t has not come to us as part of a powerful critique of anything important in the world." Id. Insofar as republicanism is, broadly speaking, "at one" with the liberalism of Mill, Dewey, and Rawls, and insofar as "legal liberalism" (a most ambiguous idea) can be understood as part of that form of liberalism, he seems entirely correct in recognizing a connection between republicanism and legal liberalism. (Of course, adherents to liberal republicanism would quibble with the word "trapped.") Liberal republicanism does, however, straightforwardly attack three ideas: (1) interest-group pluralism; (2) conceptions of prepolitical or presocial rights as the centerpiece of American public law; and (3) assumptions that existing distributions of resources, entitlements, and even preferences are neutral or just. See Sunstein, supra note 17, at 1547-58. To this extent, liberal republicanism is indeed a challenge to many things that are important "in the world."

19. Madison emplasizes this theme throughout his work, most famously in THE FEDERALIST No. 10 (J. Madison).

20. Of course, an enthusiastic belief in private property does lie at the heart of republicanism. See, e.g., J. Pocock, The Machiavellian MOMENT 462-64 (1975). A liberal republican would emphasize that private property is a creation of legal rules, rather than a prepolitical right; but liberal republicanism certainly does not, for this reason, disparage the institution of private property. The traditional liberal strand values private property for its connection with liberty and prosperity. The traditional republican strand views private property as an indispensable guarantee of security and independence from the state. In this sense, private property is a precondition for citizenship, because it protects people from dependence on the will of the sovereign. 
Under this view, the political process should strive to coordinate and reasonably accommodate different values and preferences. But preferences are not taken as prepolitical or static. They are a subject of conversation and debate-as people decide, in politics, about appropriate approaches toward contemporary problems, such as environmental degradation, broadcasting policy, labor-management relations, and racial and sexual discrimmation..$^{21}$

Three additional commitments follow from this view of political deliberation. First, liberal republicanism prizes citizenship. It does not require that all decisions be made by town meeting, 2.2 but it does not view political participation as dispensable in a well-functioning democracy. ${ }^{23}$ Liberal republicans seek to ensure that the pohitical process benefits from widespread participation by the citizenry. ${ }^{24}$ A systein without such participation is, to that extent, a failure.

Second, liberal repubhicanism is committed to umiversalism - agreement as a regulatory ideal for pohtics. Liberal republicans thus reject the view that political differences are merely matters of perspective, situation, or taste. ${ }^{25}$ On the contrary, they believe that right answers to political controversy can frequently be identified. Right answers appear as such through the ultimate criterion of agreement, reached by the citizens under appropriate conditions. ${ }^{26}$

The final commitment is to political equality, and here things are more complex. At a minimum, the commitment to political equality prohibits large disparities in the political influence of different social groups. ${ }^{27}$ Actual or virtual disenfranchisement of citizens is therefore banned. A guarantee of political equality does not, however, translate into a guarantee of economic equality. Indeed, the political creed of eco-

21. See Manin, On Legitimacy and Political Deliberation, 15 PoL. THEORY 338, 340-41 (1987) (discussing the universalist theory of justice that represents the interests of all members of society by requiring unanimity only for the "larger principles" and not for each individual decision).

22. Madison rejected classical republicanism on this ground. See THE Federalist No. 10., at 21-22 (J. Madison) (R. Fairfield 2d ed. 1966).

23. See The Federalist No. 39, at 191 (J, Madison) (R. Fairfield 2d ed. 1966).

24. Constitutions-which the citizenry itself establishes-may of course limit citizen decisionmaking. See Ackerman, Constitutional Politics/Constitutional Law, 99 YALE L.J. 453 (1989) (decisionmaking by citizens requires a serious and focused political movement that can convince a majority of fellow citizens of the merits of the proposal, while also giving the opposition the opportunity to launch its own campaign).

25. See Meyers, Beyond the Sum of the Interests, in THE MIND OF THE Founder xxiv-xxxiii (M. Meyers rev. ed. 1981).

26. In some cases, genuine consensus is impossible to achieve. The basic point is that this highly pragmatic concept of agreement constitutes the only criterion for truth. See Dewey, Propositions, Warranted Assertability, and Truth, 38 J. PHIL. 265 (1941).

27. See Sunstein, supra note 17 , at $1552-53$. 
nomic egalitarianism ${ }^{28}$ is foreign to the liberal republicanism of American public law. The American tradition rejects egalitarianism because it conflicts with three principal goals of liberal republicanism: promoting liberty; providing incentives for productive work; and rewarding and recognizing individual achievement and excellence. Insofar as regulatory and welfare progranis are founded upon egalitarian principles (and they rarely are), they are indeed inconsistent witl the hiberal republicanism that undergirds American public law.

At the same time, three narrower conceptions of equality do play an miportant role in the American administrative state. ${ }^{29}$ These narrower conceptions, sometimes identified with egalitarianism, spring in fact from quite different foundations.

The first is a belief in freedom from desperate conditions. ${ }^{30}$ No one should be deprived of adequate food, shelter, police protection, or inedical care. This principle allows for enorinous variations in living standards; it can liardly be classified as egalitarian. It does, lowever, protect people froin falling below a specified floor.

The second conception is an opposition to caste systems. The American tradition lias also traditionally disfavored such systems. ${ }^{31}$ Even so, soine current arrangeinents (including the social and legal treatinent of blacks, women, and the handicapped ${ }^{32}$ ) continue to retain caste-

28. I understand the term "egalitarianism" to connote an effort to ensure against large disparities in wealth and resources.

29. I do not claim that the Constitution coinpels any of these principles. Although soine constitutional provisions reflect ideas that are consistent with these principles (nost notably the thirteenth, fourteenth, fifteenth, and nineteenth amendinents), none of these narrower conceptions of politieal equality can claim an unambiguons constitutional home.

30. Madison and Jefferson both defended the right to a ininimunı quality of life. See Sunstein, supra note 17, at 1553 n.75. Roosevelt also endorsed this principle in his Second Bill of Rights. He noted various "econonic truths [that] have beconie accepted as self-evident. . . . Among these are: The right to a useful and renunerative job ... ; The right to earn enough to provide adequate food and clothing and recreation; ... The right of every family to a decent home; The right to adequate medical care ... . [and] The right to adequate protection from the economic fears of old age, sickness, accident, and nnemployment;...." Roosevelt, Message to the Congress on the State of the Union, in 13 The Public Papers and Addresses of FrankLin D. Roosevelt 41 (1969) (speech delivered Jan. 11, 1944).

31. See L. Hartz, The Liberal Tradition in America 3-32 (1955). Although the American tradition disfavors caste systems, it has not recognized and disapproved of every caste system as such. The two most prominent examples-the enslavenient of black people and the disenfranchisement of wonen-reveal that general principles, even if widely held, can be selectively applied.

32. Along ncarly every inportant dimension of social welfare, blacks are worse off than whites and wonien worse off than nien. See STATISTICAL ABSTRACT OF THE UNITEd STATES 420, 445-62 (110th ed. 1990). In addition, persons who are handicapped continue to face obvious barriers in a world designed by and for the able-bodied. 
like features. ${ }^{33}$ Modern administrative regimes seek to eliminate or to counteract these caste-like systems.

Finally, liberal republicanism seeks to assure its citizens rough equality of opportunity. ${ }^{34}$ Having rejected the egalitarian principle, liberal republicans nonetheless insist that the life prospects of a child born to one family im one part of the country ought not to be radically different from those of anotler child born to another family elsewhere. It is true that in a hberal society, different families will have different resources, backgrounds, and educations, and these differences constrain our ability to guarantee equal opportunity. Nonetheless, government can do much to help. It can ensure that education is available to all. It can design regulatory systems that promote awareness and understanding of public issues. It can create training and other prograins to give sohd prospects to people born in average or below-average conditions. And it can minimize the risk that economic differences will translate into large disparities in the life chances of its citizens. Ideas of precisely this sort form the basis for a nuniber of regulatory programs..$^{35}$

The cominitments of hiberal republicanism to deliberation, citizenship, umiversalism, and political equality draw from a wide range of starting points; this is no sectarian creed. The hberalisin of Mill ${ }^{36}$ and Rawls ${ }^{37}$ is entirely compatible with the account $I$ liave offered. Taken seriously, ${ }^{38}$ it calls for large-scale clianges in existing arrangeinents. In addition, certain forins of utilitariaunsm place a high premiunı on political debiberation, prize political equality, and do not take existing prefer-

33. On caste and inequality, see Sunstein, Three Civil Rights Fallacies, 79 CAL. L. REV, 751 (1991).

34. See J. Rawls, A Theory of Justice 73 (1971).

35. For example, consider education, environment, occupation, employment, and training programs.

36. See J. Mill, Considerations on Representative Government (3d ed. 1865); J. Mill, Principles of Political Economy, with Some of Their Applications to Social Philosophy (1880) [hereinafter J. Mill, Polmtical Economy]; J. Mill, The Subjection of WOMEN (2d ed. 1869).

37. See generally J. RAWLS, supra note 34, at 195-257 (discussing a "basic structure" designed for a constitutional democracy, and required to satisfy principles of justice, including the difference principle).

38. In law and elsewhere, critics have frequently caricatured the hiberal tradition in three ways: (1) as a wholehearted endorsement of interest-group pluralisin; (2) as a belief that government exists solely to protect predefined private rights; or (3) as a principle of neutrality rooted in the preservation of the status quo. See M. KelmaN, A Guide to Critical Legal Studies (1987) (treating liberalism as cominitted to pre-pohitical rights); C. MACKINNON, FEMINISM UNMODIfIED: DisCOURSES ON LIFE AND LAW (1987) (describing hberalism as rooted in an indefensible conception of neutrality). No important liberal ever subscribed to any of these ideas. See S. HoLMES, THE ANATOMY OF ANTILIBERALISM (forthcoming 1992) (discussing various mistakes of antiliberals). 
ences and distributions as the basis for social choice. ${ }^{39}$ Thus understood, utilitarianism is fully compatible with the account suggested here. Liberal republicanism is also closely hinked to certain forms of pragmatism. For example, John Dewey emphasized a conception of liberty founded on establishing the social preconditions necessary for political deliberation and free preference formation. ${ }^{40}$ Finally, the contemporary revival of Aristoteliamsm leads quite naturally to the four commitments that I have identified. This is so especially insofar as the Aristotelian revival derives from a perceived need to create social institutions that allow development of the capabilities of all citizens. ${ }^{41}$ The fact that liberal republicanism can draw from such a variety of traditions surely adds to its general appeal.42

2. The New Deal Reformation. An understanding of American administrative law cannot be obtained through a study of liberal republicanism alone. It is also necessary to explore the New Deal reformation of the constitutional franework. ${ }^{43}$ For purposes of the present discussion, the central aspect of the New Deal reformation was its attack on the system of laissez-faire.

For New Deal reformers, the very idea of laissez-faire was misconceived. ${ }^{44}$ It diverted attention from the fact that legal rules were already

39. See, e.g., R. BRANDT, A THEORY OF THE RIGHT AND THE GOOD (1979) (discussing a framework for utilitarianism that does not rest on existing preferences); J. RILEY, LIBERAL UTILItarianism: Social Choice Theory and J.S. Mill's Philosophy (1988) (same).

40. See, eg., J. DEWEY, FREEDOM AND CULTURE 18-19 (1939) ("'A] certain complex culture stimulates, promotes and consolidates native tendencies so as to produce a certain pattern of desires and purposes."); id. at 140 ("The assumption that desires are rigidly fixed is not one on its face consistent with the history of man's progress from savagery through barbarism to even the present defective state of civilization."); Dewey, Philosophies of Freedom, in FrEeDOM IN THE MODERN WORLD 236, 243 (H. Kallen ed. 1928) ("[W]e may say that a stone has its preferential selections set by a relatively fixed, a rigidly set, structure. ... The reverse is true of human action. In so far as a variable life-history and intelligent insight and foresight enter into it, choice signifies a capacity for deliberately changing preferences."); Dewey, The Future of Liberalism, in DEWEY AND HIS CrITICS 695, 697 (S. Morgenbesser ed. 1977) ("Liberalism knows that social conditions may restrict, distort, and almost prevent the development of individuality. It therefore takes an active interest in the working of social institutions that have a bearing, positive or negative, upon the growth of individuals.... It is as much interested in the positive construction of favorable institutions, legal, political, and econounic, as it is in the work of removing abuses and overt oppressions.").

41. See A. Sen, Commodities and Capabilities (1985); Nussbaum, Aristotelian Social Democracy, in Liberalism AND tHe Good 203 (N. Donglas, G. Mara \& H. Richardson eds. 1990).

42. Cf. Rawls, The Idea of An Overlapping Consensus, 7 OxFord J. LEgAl STUd. 1 (1987) (discussing capacity of the Rawlsian view of liberalism to draw from range of starting points).

43. For a more extended discussion, see C. SunSTEIN, supra note *, at 193, 210-26; Sunstein, Constitutionalism After the New Deal, 101 HARV. L. REv. 421, 425-30, 508-10 (1987).

44. Consider Roosevelt's suggestion: "We must lay hold of the fact that economic laws arc not made by nature. They are made by human beings." 1 Public Papers of Franklin D. ROOSEVELT 657 (1938). 
in place, that they did not leave matters alone, and on the contrary that they created a system that sometimes produced both inefficiency and injustice. Far from laissez-faire, the market was constructed by the rules of contract, tort, and property law, and these operated as regulatory controls, benefiting some people while burdening others. The system that preceded the New Deal could not be characterized as "natural" or "prepolitical." It represented a series of social choices embodied in law.

These propositions did not by themselves justify the rise of the regulatory state. Indeed, the assertion that a system is socially constructed is entirely neutral from the moral point of view-such an assertion does not support change. But the New Dealers also claimed that new regulatory regimes could both promote prosperity and help the disadvantaged. ${ }^{45}$ These claims largely undergirded the creation of the modern administrative state; they provide much of the focus of contemporary controversy in administrative law.

In many respects, the ideas of the New Deal reformation are highly compatible with liberal republicanism. The major difference lies in the emphatic New Deal insistence that existing distributions of resources must not be taken as natural or just, but assessed on pragmatic grounds, explorimg their consequences for economic prosperity and distributive justice. ${ }^{46}$ The modern regulatory system has grown out of this insistence, and the pragmatic assessment of regulatory programs was hardly meant to end in the 1930s. ${ }^{47}$

45. Many New Deal reforms have of course failed. For example, the effort to ensure cartelization, promiment in the early New Deal, was notoriously unsuccessful on pragmatic grounds. See E. Hawley, The New Deal and the Problem of Monopoly (1966).

46. See K. Davis, FDR: The New Deal Years 1933-1937, at 232-37 (1986) (discussing pragmatism and willingness to experiment).

47. The New Deal emphasis on the constructed character of the social framework was pragmatic and liberal, not "postliberal" or "postınodern." The reforms that have followed, or will follow, have not and need not take postmodern form. Although I agree with much of Christopher Edley's contribution to this symposium, iny uneasiness with some of it stems froin his enthusiasm for postmodernism in law. In this discussion, I restrict myself to soine brief observations on this conplex issue. For a more extended discussion, see M. NuSSBAUM, Sophistry About Conventions, in LOVE'S KNOWLEDGE 220 (1990).

First, in order to be worth holding, any position on law and politics must be justified by reference to reasons. We should not restrict ourselves to a narrow or strictly Cartesian category of "reasons," but a view unsupported by reasons is unlikely to deserve serious consideration. The postmodern position, however, appears to reject the process of reason-giving altogether, referring instead to "play," "conventions," or "power." See, e.g., J. DeRrida, Of Grammatology 50 (G. Spivak trans. 1976) (play); S. Fish, DoIng What Comes Naturally: Change, Rhetoric, aNd THE Practice of Theory IN LITERARY AND Legal Studies (1989) (conventions); M. FoUCAULT, POWER/KNOWLEdGe: SElected INTERVIEWS AND OTHER Writings, 1972-1977 (C. Gordon ed. 1981) (power). In law and politics, this substitution ensures that postmodernists "can give no account of the normative foundations of [their] own rhetoric." J. HABERMAS, The PhiLoSOPHICAL Discourse OF MODERNITY: TWELVE LECTURES 294 (F. Lawrence trans. 1986). 


\section{B. (Some of) The Limits of Markets}

No industrialized deinocracy does or could operate without a substantial regulatory state. To be sure, private inarkets usually proinote

Second, a healthy recognition of the constructed or contingent character of most of the social world points in no particular direction. In its logic, it need hardly be allied with desirable social movements. In its logic, it points nowhere at all.

Third, the fact that there is no wholly external point of view-no place, outside the world, froin which to view the world-does not lead to the conclusion that wc are left in an abyss or with the endless frec play of conficting perspectives. See M. Nussbaum, supra, at 225-27. Instead, the absence of a wholly exterual perspective means simply that participants in law and politics inust discuss what they always have: the effects of different systems on the lives of human beings who are affected by law and politics. As long as metaphysics do not intrude, truth and objectivity are not dispensable concepts in this endeavor.

Fourth, stability is not intrinsieally bad, and fluidity is not imtrinsically good. The value of change depends on the particular subject of change. To the extent that postmodernisin prizes fluidity and transformation, independently of substance, it will often point in the wrong direction. See $\mathbf{R}$. UNGER, FALSE NECESSITY (1987) (praising "context smashing").

Fifth, the postmodern approach relies too heavily on abstract clains of contingency and constructedness, and focuses too hittle on developing specific substantive remedies for injustice and inefficiency in existing systems. See, e.g., Schlag, Normativity and the Politics of Form, 139 U. PA. L. REV. 801 (1991). For example, the relationship between postmodernism and contenporary racial inequality is quite obscure. How the former can help us understand or remedy the latter remains to be explained.

Sixth, the postunodern approach tends, wrongly, to disparage instrumental rationality, which is critically important in bringing about effective change in the real world. Problems such as hoinelessness and discrimination require, for their solution, efforts grounded in instrunental reason.

Seventh, postunodernisin attempts to consolidate two positions that are actually quite incoinpatible. The first position, rooted in Heidegger and reflected in Derrida, attacks Western thought for positing a reality below "surface" appearances. See J. DERRIDA, supra. According to this view, below the surface appearances lie simply more surfaces. The second position, rooted in Marx and having clear echoes in Foucault, attempts to "unmask" thought and practices that conceal oppression, injustice, or the exercise of power. See M. Foucault, Discipline AND PUNISH: THE BIRTH OF THE PRISON (A. Sheridan trans. 1977). The task of unnasking necessarily iinplies the unveiling of a deeper truth or reality. The rejection of any underlying "reality" (a profoundly antipolitical view) does not allow for the notions of exposure or unmasking. Together, these two positions produce a range of confusions. See Schlag, "Le Hors de Texte, C'est No:" The Politics of Form, 11 CARDOZO L. ReV. 1631 (1990).

Finally, the postmodern approach depends on a critique of metaphysical realisın that has been put forth more persuasively, and with more careful attention to its implications, by Dewey, James, Putnam, and Wittgenstein, anong others. See J. Dewey, Experience AND Nature (1926); W. James, Pragmatism: A New Name for Some Old Ways of Thinxing (1928); H. Putnam, Reason, Truth and History (1981); L. Wittgenstein, Philosophical Investigations (1953). The most valuable claims here tend to come from pragniatisin, and not froin postmodernisin.

The most general way to connect these points is to suggest that the tasks of administrative law include many things: the correction of failures in the market for product safety; the creation of a stable system for the regulation of financial markets; the developinent of an energy policy that will encourage domestic production; the provision of medical care to the poor and the elderly; the regulation of unsafe conditions in the airline industry and the streets; the elimination of racial and sexual discrimination; the protection against international environınental problems such as the destruction of the ozone layer and global warning; the iucorporation of disabled people into a society built for the able-bodied; the control of carcinogens in the workplace without high unemployment or fnancial 
individual freedoin and economic welfare. Solnetimes, however, private markets fail to provide either. ${ }^{48}$ When inarkets fail, democratic controls are the only viable option. Although the arguments for social regulation are quite straightforward, they have often been derided in the last decade, particularly by the Reagan and Thatcher Administrations, as well as welfare economists and others who invoke pre-New Deal principles of private right. ${ }^{49} \mathrm{It}$ is therefore worthwhile to provide a brief outline of the reasons for social regulation. In outlining those reasons, I make no claim to special originality. My goal is simply to categorize soine of the foundations for regulatory controls.

Sometimes inarkets fail simply because consumers lack necessary infornation. For exainple, the market often fails to provide enough information about the risks posed by carcinogens in the workplace, in food, and in drugs. Economic inarkets often underproduce information, because information has soine of the characteristics of a public good. ${ }^{50}$ In such cases, regulation might remedy the problem. Through supplying information, the government also bolsters the democratic process and promotes public education. Government programs can simultaneously encourage freedom of choice and protect health and lives.

Markets also fail when they do not take full account of the costs that private conduct imposes on other people. Pollution is an obvious example. ${ }^{51}$ Environmental damage imposes severe costs, and these costs fall on numerous people. But the persons injured (not just living adults, but children and meinbers of future generations as well) lack the knowledge and organization to bring suit or otherwise seek redress. In these situations, a regulatory response, which forces those who produce harm to pay for it and ultimately to eliminate or to reduce it, is entirely justified. ${ }^{52}$

Somewhat more subtly, government controls can sometiunes facilitate an outcome that people want but cannot obtain in the marketplace.

costs; and the regulation of toxic chemicals in the air and water. The role of such concepts as "paradox," "bricolage," "meaning on the fly," or "Neurath's boat" in addressing these problems remains something of a puzzle. See Edley, supra note 3, at 594 (quoting Michelman, Postmodern Constitutionalism (unpublished manuscript)).

48. I do not deal with redistributive arguments here. For a discussion of some of the complexities, see C. SuNSTEIN, supra note *, at 55-57, 61-64.

49. See, e.g., R. EPSTEIN, supra note 10 (arguing for constitutional assault on New Deal).

50. See P. Asch, Consumer Safety Regulation: Putting a Price on life and limb $50-51$ (1988).

51. A less obvious example is the loss of endangered species, which provide a range of medicinal, agricultural, educational, and recreational benefits to human beings.

52. My usage is admittedly pre-Coasean here, in the sense that it relies on notions about causation that disregard some complex issues. The "victims" of pollution should sometimes be treated as causal actors, if they could have avoided the harm at low cost. See Coase, The Problem of Social Cost, 3 J. L. \& ECoN. 1 (1960) (discussing reciprocal nature of causation). 
For example, people may want a recycling program provided that everyone participates. They may not, however, be willing to recycle on their own unless they know that everyone will participate. A world in which everyone recycles can thus be obtained only with governmental help. A governmentally mandated recycling program can satisfy private wishes far better than the market, which is of course mcapable of mandating umiversal recycling. In this way, government can solve collective action problems and prisoner's dilemmas. ${ }^{53}$

This point helps support government controls, not only in the environmental arena, but in energy conservation, automobile safety, and other areas. In these settimgs, governmental coordination of private behavior structures and organizes private choices, and should not be seen as rejecting them.

These arguments for regulation involve standard cases of inarket failure. Even those who are firmly committed to laissez-faire should accept them im principle. ${ }^{54}$ But even where efficiency arguinents provide httle or no support for regulation, democratic principles often support government action. Sometimes the strongest arguments for regulation sound in democracy rather than efficiency. For example, people often desire pohitical outcomes that are different from and even inconsistent with their preferences as consumers. ${ }^{55}$ Some people favor stringent environmental laws even though they rarely venture outdoors; others support the protection of endangered species even though they do not personally benefit from the existence of those species; still others seek laws that forbid race and sex discrimination even though their own behavior is hardly race- or gender-neutral. As citizens, people frequently support government regulation that diverges from their behavior as consuiners. ${ }^{56}$

53. See R. Hardin, Morality WITHIN the Limits of Reason 47-59 (1988) (arguing that modern states elect rules that solve coordination and collective action problems).

54. For example, many of these arguments can be found in the final chapter of J. MiLL, PolitICAL ECONOMY, supra note 36, notwithstanding Mill's celebrated opposition to paternalism and his insistence that the only legitimate basis for government intervention is to prevent harm to others. See J. MILI, ON LIBERTY (1885) (characterizing intervention as generally counter to liberty interests).

55. See, e.g., H. Margolis, Selfishness, Aitruism, and Rationality 82-95 (1982) (discussing citizen preferences); Sen, Rational Fools: A Critique of the Behavioral Foundations of Economic Theory, in BEYOND SELF-INTEREST 25 (J. Mansbridge ed. 1990) (arguing against economic models based on egotistic behavior).

56. It is tempting to respond that political behavior is at best a confused reflection of "actual" choice because voters, unlike consumers, do not fully realize that they must bear the costs of programs they support. This explanation has some plausibility, but it is far too crude and general. For one thing, it fails to recognize that people, in their capacity as citizens, may seek to implement their highest or most altruistic goals through government. Social and cultural norms often pressure people, as citizens, to be concerned about the welfare of others and to care about the public interest. A liberal republic should not disparage these concerns. See Elster, Selfishness and Altruism, in 
Similarly, political action can and sometimes should overcome existing private preferences and beliefs. Preferences, desires, and beliefs do not exist in a vacuum; they often adapt to existing legal rules and social practices. Without the possibility of government action, current practices soinetimes seem intractable, and people resign theinselves to them. ${ }^{57}$ People adapt their behavior and even their desires and beliefs to the status quo. In such cases, there is a serious obstacle to political freedom. Freedom consists not merely in satisfying one's desires, but also in ensuring that desires are not formed under unjust conditions, or under circumstances that impede their free development. ${ }^{58}$ This concept of freedom is highly congerial to American public law. 59

If people can act in concert through government, they can remove some of these obstacles. Social movements that involve the environment, labor, einployment, poverty, anti-discrimination, and occupational health and safety are conspicuous examples. Througli the process of collective action, government can counteract constraints on preference formation.

Considerations of deinocracy therefore support regulatory programs even when the claims of economic efficiency do not. Regulation may also be justified as a means of increasing opportunities when markets fail to provide them in sufficient numbers. Government can protect the background conditions for private choice by ensuring sufficient diversity to prevent existing arrangements from constraining preference formation. ${ }^{60}$

BEyOND SELF-INTEREST, supra note 55, at 44; Jencks, Varieties of Altruism, in BeYoND SelFINTEREST, supra note 55, at 53. The collective character of politics helps to explain this phenomenon. People may seck to achieve altruistic aspirations only if they are assured that other citizens will do so as well.

57. See J. Elster, Sour Grapes: Studies in the SUbVersion of RATIONAlity (1983) (preferences underlying a choice may be shaped by unjust constraints); A. SEN, supra note 41 (same); Nussbaum, supra note 41, at 203 (discussing a social democracy that provides for "good human functioning," political mechanisms to support its citizens, and institutional arrangements that redefine the concept of private ownership). Much empirical data confirms the claim that preferences adapt to existing entitlements. See, e.g., Kahneman, Knetch \& Thaler, Experimental Tests of the Endowment Effect and the Coase Theorem, 98 J. PoL. ECON. 1325 (1990) (arguing that the minimum compensation necessary to entice an individual to give up an existing entitlement may greatly exceed the maximum price that the same individual would be willing to pay for the entitlement); Knetch, The Endowment Effect and Evidence of Nonreversible Indifference Curves, 79 AM. ECON. REv. 1277 (1989) (arguing that preferences are affected by the status quo).

58. A particular problem is the potential of race- or gender-based caste systems to accompany markets and to impede preference formation. Government controls are necessary to eliminate these caste-like characteristics. See Sunstein, Why Markets Don't Stop Discrimination, 8 Soc. PHIL. \& Pol. 22 (1991).

59. See Sunstein, supra note 17, at 1558-62.

60. See Stewart, Regulation in a Liberal State: The Role of Non-Commodity Values, 92 YALE L.J. 1537, 1560-66 (1983) (discussing need to provide conditions for free formation of preferences). In this discussion, I do not address the view that regulation sometimes redistributes resources to 
For example, some people may not value environmental diversity or endangered species simply because the market does not provide them in sufficiently visible places. A regulatory response is entirely appropriate.

All of this suggests that notwithstanding the frequent objection that governmental regulation is "paternahstic" or insufficiently respectful of private choice, ${ }^{61}$ substantial regulatory controls are often fully justified. First: In cases of madequate information, harms unaccounted for by the market, and governmental coordmation of private behavior, regulation sometimes facilitates the satisfaction of private desires and does not reject mdividual choice. Second: Regulation can vimdicate democracy by protecting collective aspirations and altruistic goals that override the outcomes of markets. This hardly constitutes an objectionable imterference with freedom. Third: Government can properly play a role in increasing available opportunities and information, and in domg so it can improve market outcomes. This is so even in a system that prizes (as all systems should) private property, freedom of contract, and other voluntary arrangements.

\section{Regulatory SuCCESSES AND FaIluRES}

\section{A. Successes}

How effective has regulation proved in practice? In fact the record shows many successes. ${ }^{62}$ Despite its popularity, the view that social regulation has generally failed is far too crude. In numerous areas-including environmental protection, automobile safety, civil rights, and the protection of endangered species-regulation has resulted in substantial improvements.

A notable example is the effort to reduce air pollution. Since 1970, both the levels and emissions of all major pollutants im the United States-imcluding sulfur dioxide, carbon monoxide, and lead-have substantially decreased. ${ }^{63}$ In addition, the vast majority of counties in the Umited States now comply with national air quality goals with respect to

groups or individuals with (or withoutl) a good claim to them. For a brief discussion of this view, see C. SUNSTE1N, supra note *, at 55-57, 61-64.

61. See supra note 10 and accompanying text.

62. See C. SunSTEIN, supra note *, at 239-41.

63. Environmental Protection Agency, Office of Air Quality Planning and Standards, National Air Pollutant Emission Estimates 2 (1990). Lead reductions have been especially dramatic. The ambient concentration of lead decreased no less than $94 \%$ between 1975 and 1981. See Table 1 infra. The effort to reduce transportation emissions has also been remarkably successful. Transportation emissions have been reduced from 122.6 million unetric tons in 1975 to merely 3.5 inillion in 1986. Conservation Foundation, State of THE ENVIRONMENT: A VIEW TOWARD THE NinetIES 152-53 (1987). Consider the following data: 
all major pollutants. ${ }^{64}$ Although substantial room remams for improvement, air in the United States is much cleaner and healthier than it would have been without regulatory controls.

Water pollution control has also achieved significant gains. The Great Lakes are much cleaner than they were in 1965, when hundreds of

\begin{tabular}{lccc}
\hline Table 1: & $\begin{array}{c}\text { National Ambient Concentration of Nitrogen Dioxide, Total Suspended Particulates } \\
\text { (TSP) and Lead } \\
\text { Nitrogen Dioxide }\end{array}$ & TSP $\left(\mu \mathrm{g} / \mathrm{m}^{3}\right)$ & Lead $\left(\mu \mathrm{g} / \mathrm{m}^{3}\right)$ \\
\hline Year & 0.029 & 61.9 & 1.04 \\
1975 & 0.029 & 62.8 & 1.05 \\
1976 & 0.029 & 62.9 & 1.16 \\
1977 & 0.029 & 62.4 & 1.04 \\
1978 & 0.029 & 63.4 & 0.79 \\
1979 & 0.028 & 64.8 & 0.55 \\
1980 & 0.027 & 60.2 & 0.44 \\
1981 & 0.026 & 50.2 & 0.47 \\
1982 & 0.025 & 49.7 & 0.39 \\
1983 & 0.026 & 50.9 & 0.35 \\
1984 & 0.025 & 48.5 & 0.23 \\
1985 & 0.025 & 48.4 & 0.15 \\
1986 & 0.025 & 49.4 & 0.12 \\
1987 & & 0.4 &
\end{tabular}

SOURCES: COUNCIL ON ENVIRONMENTAL QUALTTY, ENVIRONMENTAL QUALITY ANNUAL REPORT 1987-88, 351 (Table 3-4) (1989); COUNCIL ON ENVIRONMENTAL QUALITY, 20TH ANNUAL REPORT, 469 (Table 41) (1991).

COMMENTS: Nitrogen dioxide contributes to acid deposition as well as causing adverse health effects. TSP is a measure of overall concentrations of particulate matter in the air. Lead causes a variety of adverse health effects. Nitrogent dioxide and TSP reductions have been relatively modest.

Table 2: National Ambient Concentrations of Sulfur Dioxide, Carbon Monoxide and Ozone by Parts Per Million

\begin{tabular}{lccc} 
Year & Sulfur Dioxide & Carbon Monoxide & Ozone \\
\hline 1975 & 0.015 & 11.96 & 0.153 \\
1976 & 0.016 & 11.32 & 0.153 \\
1977 & 0.015 & 10.66 & 0.155 \\
1978 & 0.014 & 10.17 & 0.156 \\
1979 & 0.012 & 9.80 & 0.142 \\
1980 & 0.011 & 9.08 & 0.145 \\
1981 & 0.010 & 8.82 & 0.131 \\
1982 & 0.0098 & 8.13 & 0.128 \\
1983 & 0.0094 & 8.02 & 0.145 \\
1984 & 0.0095 & 8.00 & 0.130 \\
1985 & 0.0089 & 7.19 & 0.127 \\
1986 & 0.0086 & 7.21 & 0.123 \\
1987 & 0.0084 & 6.88 & 0.129
\end{tabular}

SOURCES: COUNCIL ON ENVIRONMENTAL QUALITY, ENVIRONMENTAL QUALITY ANNUAL REPORT 1987-88, 351 (Table 3-4) (1989); COUNCIL ON ENVIRONMENTAL QUALITY, ENVIRONMENTAL QUALTTY 20TH ANNUAL RePORT, 469 (Table 41) (1991).

COMMENTS: Sulfur dioxide contributes to acid deposition and visibility impairment. All threc of these pollutants cause additional adverse health effects. The data suggests that legislation has been fairly successful at reducing the ambient concentrations of each of these pollutants, although it is not clear that the reductions reached predicted levels. All three have declined steadily over the last eleven years, most notably sulfur dioxide.

64. See Council on Environmental Quality, Environmental Quality: The TwenTIETH ANNUAL REPORT OF THE COUNCIL ON ENVIRONMENTAL QUALITY 8-9 (1990) (discussing environmental trend data and noting several pollutants that have been reduced to meet national health standards in most areas of the country). 
beaches had to be closed.65 The reductions in levels of DDT, PCB, and dieldrin contaminants in Great Lake fish have been especially dramatic. ${ }^{66}$ A number of harmful nutrients have been reduced by nearly fifty percent in national rivers. ${ }^{67}$ Lead levels in our waters have also been significantly reduced. ${ }^{68}$ As a result, inany rivers are inuch cleaner on balance, including the Potomac, the Hudson, and parts of the Mississippi. ${ }^{69}$

Regulatory successes have not been limited to the environment. The Civil Rights Act of 1964 has produced gains for blacks, including decreases in employinent discrimination based on race. ${ }^{70}$ Similar gains have been achieved in combatting sex discrimination. ${ }^{71}$

Several other regulatory prograins impressively accomplished their goals. For example, the automobile safety regnlations promulgated in the late 1960 s and early $1970 \mathrm{~s}^{72}$ have prevented numerous injuries and saved lives. According to one estimate, automobile fatalities would have been about forty percent higher in 1983 if not for governinental controls. ${ }^{73}$ In addition, an estimated 34,000 hives were saved between 1966 and 1974 as a result of occupant safety standards. ${ }^{74}$ The annual benefits of automobile regulation are extremely high-estimated at over $\$ 10$ bilhon. ${ }^{75}$ Moreover, there is a favorable ratio of benefits to costs in this area. ${ }^{76}$

\footnotetext{
65. Council on ENVIRONMENTAL QUALITY, supra note 64, at 325-36, 346-70; C. SUNSTEIN, supra note *, at 77 .

66. Council on ENVIRONMENTAL QUALITY, supra note 64, at 319-21.

67. See id.; Council on ENVIRonmental Qualtry, ANnUAL Report 1987-1988, at 31826.

68. See Conservation Foundation, State of the Environment 90 (1987).

69. Crandall, Learning the Lessons, 11 WiLson Q. 69, 69 (1987).

70. Id. at 80 . The disputes in the empirical literature generally dcal with the magnitude of the change, not its direction. See Freedman, Changes in the Labor Market for Black Americans, in Brookings PAPERS on Economic Activity 67 (1973); Donohue \& Heckman, Re-Evaluating Federal Civil Rights Policy, 79 GEo. L.J. 1713, 1715-22 (1991); Heckman \& Paynor, Determining the Impact of Federal Antidiscrimination Policy on the Economic Status of Blacks: A Study of South Carolina, 79 AM. ECON. REv. 139 (1989); Leonard, The Impact of Affirmative-Action Regulation and Equal-Employment Law on Black Employment, 4 J. ECoN. PERSP. 47 (1990).

71. See Donolue, Prohibiting Sex Discrimination in the Workplace: An Economic Perspective, 56 U. CHI. L. REv. 1337, 1360-62 (1989) (noting that since Title VII's equal employment opportunity intiatives were enacted, the earnings and occupational positions of woinen and blacks have improved dramatically), and citations therein.

72. See e.g., Federal Motor Vehicle Safety Standards, 49 C.F.R. $\$ 371.21$ (1969).

73. R. Crandall, H. Gruenspecht, T. Keeler \& L. LaVe, Regulating the automoBILE 75 (1986).

74. Id. at 57.

75. Id. at $77-78$.

76. For example, the National Highway Traffic Safety Administration's (NHSTA) fuel system integrity controls costs only $\$ 300,000$ per life saved. See C. SUNSTEIN, supra note *, app. B at 239 41. Some regulations pay for themselves purely in terms of hcalth and related savings. See R. Crandall, H. Gruenspecht, T. Keeler \& L. Lave, supra note 73, at 78-79. Other initiatives
} 


\section{B. Failures}

To emphasize regulatory successes is not to deny that regulation has frequently failed. In some cases, regulatory controls have accomplished little or nothing. In others, regulation has imposed enormously high costs for speculative benefits. Moreover, regulation has sometimes aggravated the very problem that it was designed to solve. ${ }^{77}$ Regulatory strategies often produce insufficient benefits, and sometimes they create affirmative harm.

For example, between 1972 and 1985 the United States spent over $\$ 632$ billion for pollution control. ${ }^{78}$ Some studies suggest that alternative strategies could have achieved the same gams at nearly one-half the cost. ${ }^{79}$ Some of OSHA's regulations impose enormous costs for uncertain gains. ${ }^{80}$ The Environmental Protection Agency (EPA) has promulgated only seven regulations to control toxic substances in the air, ${ }^{81}$ and numerous substances reinain uncontrolled. By delaying the entry of beneficial drugs into the market, the Food and Drug Administration has dramatically mcreased risks to life and health in some settings. ${ }^{82}$

Regardless of how the gaims and losses fron social regulation are valued, there can be little doubt that there is far too much government regulation in some areas, and far too little in others. ${ }^{83}$ Even more funda-

have also saved lives cheaply. The Environmental Protection Agency's (EPA) regulation of trihalomethanes saves a life at only $\$ 315,000$. The Consumer Product Safety Commission's mandatory smoke detector rule costs betwecn $\$ 0$ and $\$ 85,000$ for every life saved. See C. SUNSTEIN, supra note ${ }^{*}$, at app. $\mathbf{B}$, for an outline and discussion.

77. See Sunstein, Paradoxes of the Regulatory State, 57 U. CHI. L. Rev. 407 (1990).

78. B. Ackerman \& R. Stewart, Reforming Environmental Law: The Democratic Case for Market Incentives, 13 Colum. J. ENvTL. L. 171, 177 (1988) (citing OfFice of Policy PlanNing AND Evaluation, Environmental Protection Agency, The Cost of Clean Air and Water (1984)).

79. See T. Tietenberg, Emissions Trading: AN Exercise in Reforming Pollution PoL1CY 41-45 (1985) (six of eight studies that compared command-and-control allocation with lowcost allocation found that command-and-control pollution programs cost $78 \%$ more than necessary).

80. Indeed, some of the Occupational Safety and Health Administration's (OSHA) unost expensive workplace regulations have produced no discernible inprovements for workers. See W. VISCUSi, Risk by Choice: Regulating Health AND SAFETy IN THE WoRKPLACE 25-36 (1983). Morcover, the entire patteru of OSHA carcinogen regulation is questionable. Some regulations cost up to $\$ 40$ million per life saved; at the same time, unany carcinogenic hazards remain completely unregulated. See J. Mendeloff, The Dilemma of Toxic Substance Regulation 21-24 (1988) (cost per cancer death prevented, with regard to vinyl chloride, is $\$ 40$ million (in 1985 dollars)).

81. See Note, Toward Sensible Regulation of Hazardous Air Pollutants Under Section 112 of the Clean Air Act, 63 N.Y.U. L. REV. 612, 613-14 (1988).

82. See, e.g., H. Grabowski \& J. Vernon, The Regulation of Pharmaceuticals 9-13, 29-47 (1983) (discussing the slower rate of pharmaceutical innovation as a result of government regulation and citing several studies that support this claim).

83. The use of cost-benefit analysis to measure the successes and failures of regulation can raise serious problems. These problems are especially severe insofar as we rely, as econoinists usually do, 
mentally, in many areas the question is not whether the level of government regulation is appropriate, but whether the government has chosen the suitable strategies to accomphish its goals. ${ }^{84}$

I have discussed eases in which regulation has been both mefficient and ineffective. From the standpoint of democracy, regulation has frequently failed as well. First, education about the nature and level of risks in the environment and in the workplace has not been a high priority for regulators. On this score, the public is poorly informed and thus extremely ill-served. Partly because of the absence of education and disclosure, pubhic participation and real accountability on questions of regulation have not characterized the rise of inodern bureaucracy. Instead, sensational but misleading anecdotes and interest-group pressures have played a far too prominent role.

Second, the centralization of policy in national bureaucracies diminishes the prospects for local decisionmaking in the private or public sector. Local decisions mculcate a sense of responsibility in citizens and encourage participation far more effectively than centralization. The current system unnecessarily sacrifices the values of federalisin.

on soine version of private "willingness to pay" as the basis for assessing costs and benefits. As I have noted, social regulation is often based on the values reflected in democratic aspirations rather than on private consumption choices. See supra notes 57-61 and accoinpanying text. In these cases, valuing costs and benefits by private willingness to pay can produce perverse results, because this process measures the worth of democratic aspirations by reference to the very consumption choices that democracy attempts to override.

Moreover, the conversion of diverse social goods into a dollar value inay poorly reflect citizens' considered judgments about regnlatory outcomes. For example, economic "use value" may inappropriately value the interest in beaches, streams, and animals. Economic valuations of these resources may do violence to the way that these resources are, or should be, experienced. On the other hand, tradeoffs in regulation are inevitable, and resolving tradeoffs without reference to economic considerations is usually most difficult.

Finally, willingness to pay is a function of ability to pay. In a world with an unequal distribution of mcome and wealth, it will be controversial to assert that government policy should be determined by how much people are able to pay for things such as environmental quality and occupational safety and health. For more discussion of these issues, see M. NUSSBAUM, Love's KNOWLEDGE: ESSAYS ON PHILOSOPHY AND LITERATURE 56-66 (1990) (discussing diversity of social goods); C. TAylor, Philosophy and the Human Sciences 230, 243 (1985) (same); Anderson, Values, Risks, and Market Norms, 17 PHIL. \& PUB. AFF. 54, $57-59$ (1987) (democratic willingness to spend money to avoid certain risks is based on considered judginent that public responsibility is greater in some situations than in others).

Notwithstanding these problems, cost-benefit analysis can be an exceptionally useful tool to compare the advantages and disadvantages of regulatory strategy. It can reveal when the gains of regulation are far greater than the losses, or when the reverse is true. And it is striking to see that a comparison of costs and benefits often shows that social regulation has been successful. See supra notes 62-76 and accoinpanying text.

84. See Howse, Prichard \& Trebilcock, Smaller or Smarter Government?, 40 U. TORONTO L.J. 498 (1990) (discussing shift towards incentive-oriented policy instrmments to achieve public policy goals). 
Finally, the current regulatory framework does not focus national attention on the central issues-the appropriate nature, extent, and level of risk reduction. Instead, Congress centers its efforts on obscure or incomprehensible questions. The combined effects of lack of publicity and education, nationalization, and failure to focus on the central issues of regulatory policy have severely compromised the democratic goals of American public law.

\section{The Sources of Failure}

The preceding examination of the regulatory state reveals a range of successes and failures. Prevention of the failures is a central challenge for those concerned about improving the system for the future. In meeting this challenge, the first step is to identify the sources of failure.

A number of factors are relevant liere: the government's inability to coordinate different programs that cover related aspects of the same problein; Congress's unwillingness to understand that regulatory programs involve complex tradeoffs among competing social goals; interest group "capture" of the regulatory process (an important but overstated phenomenon); and failure on the part of agencies to deal with regulatory obsolescence over time. But an especially pervasive and often overlooked problem is structural. It involves the creation of poor incentives, rather than the hiring of opportunistic or susceptible administrators. Above all, social regulation is pervaded by strategies that have unanticipated systemic consequences, that deal with the symptoms rather than the causes of social problems, that direct attention to the wrong places, and that are insufficiently sensitive to the pressures that they impose on regulators and the private sector.

A large source of regulatory failure in the Umited States is the use of rigid, highly bureaucratized "command-and-control" regulation. The resulting programs dictate national control strategies for hundreds, thousands, or even millions of compames and individuals in an exceptionally diverse nation. Command-and-control regulation is a dommant part of American government in such areas as environmental protection and occupational safety and health.

In the environmental context, command-and-control approaclies usually take the form of regnlatory requirements of the "best available technology" (so-called BAT requireinents). ${ }^{85}$ BAT strategies pervade

85. BAT strategies must be distinguished from so-called "technology forcing" statutes, which do require innovation. See B. Ackerman \& W. Hassler, Clean Coal/DirTy AIR: Or How the Clean air act Became a Multibillion-Dollar Bail-out for High-Sulphur Coal Producers and What Should Be Done about IT (1981). Technology-forcing has often accomplished considerable good. The major drawback of technology-forcing is that government is 
federal law. Indeed, they are a defining characteristic of the regulation of the air, water, and workplace conditions. ${ }^{86}$

One of the many problems with BAT strategies is that they systematically ignore the enormous differences among plants, industries, and geographical areas in the United States. In view of these differences, nationally uniform technological requirements are wildly inefficient. It does not seem sensible to impose identical technological requirements on diverse industries-regardless of whether they are polluted or clean, populated or empty, or expensive or cheap to clean up.

The problems go deeper still. BAT requirements usually apply only to new entrants in the market. By requiring all new industries to adopt costly technology while allowing existing plants and industries to conform to inore lement standards, BAT strategies penalize new products. In this way, they discourage investment and perpetuate old, dirty technology. In the environmental arena, for example, BAT strategies discourage new pollution control technologies by requiring that imdustries adopt new technology for no financial gain. Under the BAT approach, a company that innovates im this area will simply have to invest more in pollution control. BAT requirements pumsh such companies for their development of new control technology, rather than rewarding them. In addition, BAT strategies are extremely expensive to enforce, imposing extraordimary monitoring burdens on agencies that employ them. ${ }^{87}$

Perhaps worse, by focusing on the technology at the end of the pipe, BAT strategies are aimed at superficial symptoms rather than underlying causes of pollution. For example, the EPA has forced coal-fired power plants to adopt costly "scrubbing" strategies to deal with sulfur dioxide emissions that cause acid rain. ${ }^{88} \mathrm{~A}$ far better approach would use financial incentives to encourage American consumers and industries to imcrease energy conservation and efficiency, and to shift to cleaner, renewable fuels.

usually not in the best position to judge the amount of technological advance that is realistic or desirable. A good portion of these programs depends on government guesswork.

86. See Clean Air Act, 42 U.S.C.A. $§ 7411$ (a)(1) (West Supp. 1991) (standard should reflect the "degree of emission limitation achievable through the application of the best system of emission reduction"); Clean Water Act, 33 U.S.C. § 1316(a)(1) (1988) (standard determined by "the best available demonstrated control technology"); Occupational Safety and Health Act of 1970, 29 U.S.C. $\$ 655(b)(5)$ (1988) (standard should reflect "latest available scientific data in the field"). In my criticisms here, I draw on the helpful discussion in Ackerman \& Stewart, Reforming Environmental Law: The Democratic Case for Market Incentives, 13 Colum. J. ENvTL. L. 171 (1988).

87. See, e.g., Occupational Safety \& Health Admin., U.S. DeP'T of Labor, Report of the PREsident to The Congress on Occupational Safety and Health for Fiscal Year 1988 xiv (1990) ( $\$ 151,702,000$ out of total OSHA 1988 fiscal year budget of $\$ 235,474,000$ allocated to federal and state enforcement).

88. See B. Ackerman \& W. Hassler, Clean Coal/Dirty Air (1981). 
Most fundamentally, the BAT approach is severely deficient from the standpoint of a well-functioning political process. BAT strategies ensure that citizens and representatives will focus their attention on largely incidental and nearly impenetrable questions about currently available technologies, rather tlian on the appropriate levels of reduction. ${ }^{89}$ Technological debates are singularly ill-suited for deinocratic resolution. They also distract attention from the central issue of determining the appropriate degree and nature of regulatory protection. Moreover, the focus on "means" increases the power of well-organized private groups, by allowing them to use regulation to serve their own parochial ends. The promotion of etlianol (helpful to corn farmers although not necessarily to environmental protection) and scrubbers (helpful to the eastern coal industry although not necessarily to air quality) are prominent examples of interest group influence on BAT-focused systems.

In these respects, BAT strategies are emblematic of a large problein in current regulation. Centralization at tlie national level diminishes opportumities for citizen participation; it also promotes struggles among well-organized factions. The focus on technological details and sensational incidents ensures that public education about risk levels and risk comparisons will be incomplete and episodic. These characteristics of contemporary administrative law fall far short of guaranteeing democratic control over decisions about how best to characterize and to achieve social goals.

Another problein, reflected well in BAT strategies, is the creation of what we might call paradoxes of the regulatory state. 90 These paradoxes occur wlien programs turn out to be self-defeating, in the sense that they bring about results that are precisely opposite of those intended. As noted, regulation that requires the best available technology actually discourages technological development. By imposing expensive requirements on companies that develop better pollution control equipment, BAT strategies stifle actions that could lead to enormous gains in cleaning up the environment.

Much American regulation (imcluding BAT strategies) also embodies the paradox created by the idea that especially stringent controls should be imposed on new sources of pollution, and that existing industries should be regulated leniently or not at all. This is a strategy that existing industries favor, since it allows regulation to stifle new competition. The paradox arises because a decision to regulate only new health and safety risks will perpetuate old risks, and ultimately inpair health

89. See Ackerman \& Stewart, supra note 86.

90. See generally Sunstein, supra note 77 (suggesting reforms to restructure regulatory institutions). 
and safety. New risk strategies increase the costs of new sources and products, encourage consumers to resort to older sources and practices, and perpetuate the use of old, especially dirty facilities (like power plants) and products (like automobiles). ${ }^{91}$ Existing industries can be expected to favor these types of strategies, but the reasons for doing so bear no relation to rational regulatory outcomes.

A final regulatory paradox, also embodied in BAT approaches, is that strict government controls, and legal requirements that forbid tradeoffs, produce underregulation as well as overregulation. Strict regulation-apphed umiversally without regard to the diversity of the regulated class-will, of course, bring about overregulation of some of those who are subject to regulatory requireinents. The substances that are regulated will be stringently controlled-in all likelihood too stringently, forcing people to incur exceptionally high costs for speculative gains. ${ }^{92}$

Iromcally-and here is the paradox-stringent controls produce underregulation as well. The threat of draconian regulatory requirements gives imdustries powerful incentives to fight regulation wherever they can, and gives agencies a powerful incentive not to promulgate or enforce them. If Congress requires any regulation mandating multi-nillion dollar expenditures that will save but one life per year, the agency will predictably promulgate stringent, but few, regulations.

It should therefore coine as no surprise that despite (or, better, because of) the stringency of the relevant laws, the government has regulated ouly seven toxic air pollutants (out of hundreds), ${ }^{93}$ fewer than a dożen toxic water pollutants (again, out of hundreds), ${ }^{94}$ and until relatively recently, only ten toxic substances in the workplace 95 (even though the private organization that perforned some of OSHA's functions had for several years recommended lower exposure limits for hundreds of chemicals ${ }^{9}$ ).

The picture that emerges from this discussion is not a simple one. In sonie areas, government regulation has produced significant improve-

91. See R. Crandall, H. Gruenspecht, T. Keeler \& L. LAve, supra note 73, at 89. For instance, a good way to imcrease automobile pollution in the short run is to impose extremely costly pollution control requirements on new cars. Some existing motor vehicle regulations do precisely that. See, e.g., 42 U.S.C.A. $\$ \S 7521-7554$ (West Supp. 1991) (establishing new motor vehicle emission and fuel standards).

92. See J. Mendeloff, supra note 80, at 24-26.

93. See Note, supra note 81, at 613-14.

94. See F. ANderson, D. Mandelker \& D. Tarlock, Environmental Protection 439 43 (1990).

95. See J. MENDELOFF, supra note 80 , at 2.

96. See id. 
ments. In others, regulation has been counterproductive, ineffectual, overly costly, or nonexistent.

The failings of regulation need not be attributed to legislative ignorance or irrationality; some of the problems quite plausibly result from the self-interest of affected groups or of legislators themselves. For example, a decision to regulate new risks, while leaving old ones unaffected, may be a mechanism by which existing industries use regulation to prevent new competition. In addition, technology-based regulation provides a system whereby industry can slow down regulation; such strategies are vulnerable to plausible lawsuits proclaiming that existing technology is quite primitive. Moreover, legislators can claim credit for enacting stringent protections, while assuring industry that it will not in fact be regnlated at all, because any resulting regulation would be too dracomian to be enforceable. In these respects, regulatory failures can often be understood as a predictable legislative response to the various forces imposed on legislators.

In any case, faulty structures have caused many of the failures: measures that do not take account of the incentive effects of government strategies, address only part of complex problems, focus on symptoms rather than causes, and publicize misleading anecdotes rather than educating the public and benefitting from its imvolvement in the regulatory process.

\section{Regulating With INCENTIVES}

This account of regulatory performance should help produce a set of entirely feasible reform strategies. Above all, new strategies would seek to ensure that regnlation is efficient and effective, in the sense that the programs would promote their own purposes at reasonable costs. These reforms would also promote democratic goals, by ensuring accountability, visibility, and participation in the administrative process. There is no reason to beheve that these strategies cannot be implemented through existing institutions. In fact, Congress and administrative agencies have already moved in precisely this direction. ${ }^{97}$ Legislative imcentives will sometimes push toward the status quo, but recent listory shows that there is no reason to believe that this is an insuperable problem.

\section{A. General Lessons}

At the most general level, an examination of regulatory performance demonstrates that regulators should pay attention to the incentive effects of regulatory statutes. Pohcymakers should be aware of the possibility of

97. See, e.g., Clean Air Act, 42 U.S.C.A. $\S \S 7651-76510$ (West Supp. 1991). 
strategic or self-interested adaptation by administrative agencies or by members of the regulated classes. The failures of many existing strategies were perfectly predictable responses to the often-counterintuitive incentives created by those strategies. ${ }^{98}$

Regulators should encourage industry to address harms at their source. In general, regulators should adopt strategies that will reduce the introduction of dangerous substances, instead of merely controlling substances that have already been introduced. In this regard, strategies that leave the means of obtaining reduction to imdustry, rather than specifying them in detail, will prove inost effective im eliminating social harms. Rather than imposimg complex technological requireinents on pollutants as they exit the tailpipe, it would be best to eliminate lead and other dangerous pollutants from gasoline before they enter the tank. Pollution prevention, rather than technological fixes, should guide environinental policy. 99

Moreover, Congress should provide mdustries with incentives that favor regulation, where this is desired, rather than giving thein reason to oppose government controls. Existing law makes regulation extremely costly for industry and puts an enormous premium on countermeasures and delay. The best way to ensure that regulations will be issued is to create imcentives for industry to favor thein. This strategy allows the burden of inertia to work for the establishment of safety levels rather than against it. In the area of toxic substances, for example, regulators might (as California currently does ${ }^{100}$ ) require industries to disclose the existence of risks to the public until a regulation has been issued that establishes that the risks are insignificant. Unfortunately, however, most existing law creates powerful incentives for inaction and delay. ${ }^{101}$

98. For this reason many observers have concluded that Congress actually sought the failures. See Stigler, The Theory of Economic Regulation, in Chicago Studies IN POLITICAL Economy, supra note 10, at 209 (on the interaction of party politics and industry regulation); Pashigian, Environmental Regulation: Whose Self-Interests Are Being Protected?, in ChlCago STUdies IN PoLITICAL ECONOMY, supra note 10, at 498 (elevating the role of self-interest in explaining the regulation of stationary sources). The evidence does not, however, clearly support this view. See R. ARNOLD, THE LOGIC OF CONGRESSIONAL ACTION 225 (1990) (asserting that congressional action in energy regulation cannot be explained through standard interest group or ideological models; such action has resulted from complex interaction among citizen, expert, and politician attitudes and restructuring of legislative situations by coalition leaders).

99. This approach is encouraged in B. Commoner, Making Peace with the Planet 41-55 (1990). Pollution prevention is, however, undesirable when the pollutant in question cannot feasibly be eliminated, or when its elimination will produce ancillary social losses that outweigh the benefits.

100. See Roe, An Incentive-Conscious Approach to Toxic Chemical Controls, 3 EcoN. DEv. Q. 179 (1989). For a good critical discussion, see Stenzel, Right-to-Know Provisions of California's Proposition 65: The Naivete of the Delaney Clause Revisited, 15 HARV. ENV. L. REv. 493 (1991).

101. See J. MENDELOFF, supra note 80, at 137. 
Regulatory reform can directly incorporate the lessons of regulatory failure. A general first step would be to adopt a strong presumption in favor of flexible, market-oriented, incentive-based regulatory strategies. This primciple ineans that Congress and administrators should impose costs on people who engage in harmful activity, and should allow the Inarket, rather than bureaucracies, to decide how that activity will be dinimished. Such an approach would make it more likely that regulation will increase efficiency, promote its own purposes, and-by focusing pubhic attention on the right questions-further democratic goals as well.

Incentive-based systems should focus on ends, defined in terms of the number of lives saved or the amount of pollution reduced, rather than on the means of achieving those ends. ${ }^{102}$ Means (and technologies) are best left to the market, not to bureaucrats. This strategy would also avoid the numerous difficulties found in systems that require government to establish specific technological requirements for industry. ${ }^{103}$ Ideally, the deinocratic process would impose appropriate penalties, in the form of taxes designed to discourage and reduce the risks after determining what the level of risk reduction should be.

An advantage of a shift in emphasis from means to ends would be that citizens and representatives would decide the central questions of how much pollution reduction there should be, and at what cost, rather than resolving incidental and often incomprehensible questions of what "technology" is "best." The current system stifles democratic engagement im regulatory choices by entangling public processes in debates of the latter sort. The fixation on means also creates incentives for interest groups to ensure that they are favored in the legislature or in the bureaucracy. By contrast, a system of disclosure and financial penalties allows little room for interest-group maneuvering. In this respect, an incentivebased approacli has enormous advantages over the current system. ${ }^{104}$

A focus on ultimate ends also promotes coordination and rationality in regulation, by giving government an incentive to attend to appropriate risk levels in different areas, ${ }^{105}$ and by bringing a salutary measure of

102. The new Clean Air Act amendinents take several steps in this direction. See 42 U.S.C.A. $\S \S 7403-7431$ (West Supp. 1991) (toxic substances provision focuses on emissions levels rather than means of reduction); id. $\$ \S 7651-76510$ (acid deposition provisions focus on emission levels). It is extremely unfortunate that in its regulation of automobile pollution, the Act specifies means. See id. $\S 7545(k)$ (requiring reformulated gasoline-likely a reflection of pressures from agricultural community). Rather than requiring reformulated gasoline or increasing mileage standards, a better approach would simply tax gasoline, or tax the use of high-polluting vehicles.

103. See supra text accompanying notes 85-96.

104. See Ackerman \& Stewart, supra note 86.

105. See C. SunSTEIN, supra note *, app. B at 239-40 (cataloging expenditures per life saved and demonstrating the irrationality of modern regulatory programs across different areas). 
structure and sense to risk regulation. Indeed, the major advantage of incentive-based approaches may be the increase in democratic accountability results from this cognitive shift.

Incentive-based approaches may be employed in a variety of contexts, including environmental protection, occupational safety and health, labor, and broadcasting.

\section{B. Particulars}

1. Market-Based Incentives in the Environmental Area. A system in which polluters must pay for the harms they cause leads governinent to focus on the right questions. To ask how much pollution reduction should be obtained, and at what price, will create strong incentives to improve knowledge of the effects of pollution and pollution control. This increased preimum on knowledge would be yet another gain. I focus here on emissions trading, taxation, and disposal systems.

a. Emissions trading programs. An important and increasingly used incentive-based system is "eimissions trading." Under einissions trading programs, polluters who exceed air pollution standards ${ }^{106}$ can purchase permits from other polluters who are below the maximuin levels. Polluters may legally exceed the regulatory standards if they obtain a permit to do so. If the eimissions trading program is correctly administered, a region will meet the same pollution standards overall; those who pollute too much will be balanced by those who reduce more than they must. The price of the permits is determined by the market. ${ }^{107}$

In its ideal form, eimissions trading would make two simple changes in current law. First, it would require polluters to pay to pollute. It would not (as does current law) allow people to pollute for free. If a coinpany wants to send sulfur dioxide into the air, it must pay a fee to obtain a permit to do so. Second, pollution permits would be tradeable. ${ }^{108}$ A company that is able to reduce its pollution below the permitted level could sell all or part of its permit to someone else. In this way, compamies would be economically rewarded for achieving substantial pollution reduction.

In one bold stroke, a system of tradeable permits would create inarket-based disincentives to pollute and market-based incentives for pollu-

106. E.g., Clean Air Act, 42 U.S.C.A. $\$ \$ 7403-7431$ (West Supp. 1991))

107. For discussion of emissions trading, see Hahn \& Hester, Where Did All the Markets Go? An Analysis of EPA's Emissions Trading Program, 6 Y ALE J. ON REg. 109 (1989).

Of course, emissions trading is only one part of a sensible environmental program. For the most dangerous pollutants, pollution prevention is the preferred strategy.

108. See supra note 102 (discussing new Clean Air Act). 
tion control. By enlisting the aid of private markets, this system would reward rather than punish technological innovation in pollution control.

Many observers persuasively argue that the Clean Air and Clean Water Acts should be amended to substitute an emissions trading program for the BAT approach. ${ }^{109}$ Suitably designed, emissions trading holds enormous promise. Such programs do not require a single level of technology, determined by officials in Washington for all industries. In fact, trading programs eliminate the need for centralized, national determimations of what technology is "available" or feasibly available in the future.

Soine argue that emissions trading should be rejected on the theory that it creates a "license to pollute," or that it wrongly treats clean air or water like any other commodity traded on markets. ${ }^{110}$ These commentators point out that those who assault or poison others should not be allowed to do so merely by paying a fee. ${ }^{111}$ Why, it might be asked, should pollution be treated differently?

This objection raises conıplex issues, and I restrict myself to some brief observations here. As a first approximation, a flat ban on an activity may well be preferable to a cash payment for resulting harm, assuming that there are no transaction costs (such as enforcenient expenditures), when and only when the right level of the underlying activity is zero. The right level of assaults and poisonings seens to be zero. It would therefore be absurd to allow people to assault and poison others as long as they are willing to compensate people for the harm. Such a strategy would be inconsistent with the underlying goal of eliminating the conduct altogether. ${ }^{112}$

By contrast, the appropriate emissions level for many pollutants is well above zero. For example, complete elimination of sulfur dioxide emissions would cause a severe energy shortage - one that would dramatically increase poverty, health risks, unemployment, and inflation. In this respect, a ban on sulfur dioxide emissions would be difficult to justify. For those pollutants whose continued emission is necessary to

109. See Ackerman \& Stewart, supra note 86; Hahn \& Hester, supra note 107.

110. See S. Kelman, What PRICE INCENTIVes?: ECONOMISTS AND THE ENVIRONMENT 1-11 (1981).

111. See id.

112. Cf. Dau-Schmidt, An Economic Analysis of the Criminal Law as a Preference-Shaping Policy, 1990 DUKE L.J. 1 (arguing that society will criminalize a particular activity and attempt to shape individual preferences and behavior through punishment whenever the social benefits of doing so outweigh the social costs). 
achieve desirable social goals, a fee, designed to bring about the optimal emissions level, makes far more sense than a ban. ${ }^{113}$

Still, emissions tradimg has critics, mcluding many environmentalists. ${ }^{114}$ To be sure, implementation of such programs would require careful design and administration to ensure (among other thimgs) that large numbers of polluters who receive permits through trades do not locate in the same areas, thus creating dangerous "hot spots"- that is, environmentally disastrous concentrations of harmful substances. ${ }^{115}$

In general, however, most of the criticisms are unpersuasive or illinforned. For example, emissions trading prograins will not increase pollution levels. Such programs simply achieve the desired degree of pollution reduction at the lowest possible cost. If the ultimate goal is to reduce pollution sharply, then we should simply issue few pernits. As noted, emissions tradimg systems offer the great advantage of putting the power of decidimg pollution levels back into the hands of the citizenry, rather than focusing on the often unintelligible question of what control technology is "best" or "available."116 Public institutions will decide the ultimate and most important environinental policy issues, rather than the confusing and ouly imdirectly relevant questions that current law inakes

113. This proposition is only a first approximation. A decision to allow harmful activity as long as the actor is willing to pay for it might be objectionable on other grounds. Such decisions might treat the relevant imterests as commodities, and it may be wrong to do so. Decisions to allow harm. ful conduct at a price might also have undesirable preference-shaping effects. In the context of socially necessary activities that produce mcidental pollution, however, these objections seem unpersuasive.

A system that requires polluters to pay, rather than allowing them to pollute for free, would not diminish the social opprobrium accorded to polluters. Perhaps most likely, a payment-based system would not have any substantial preference-shaping effects. Moreover, the arguments against treating harmful conduct as a commodity do not appear to apply in the context of pollution control. See Radin, Market-Inalienability, 100 HARV. L. REV. 1849 (1987) (arguing that soine harmful conduct should not be "commodified" because of the resulting injury to "personhood"). In addition, shifting the entitlement from the polluter to the public (by requiring the polluter to pay) could have desirable preference-shaping effects. This decision at least establishes the right starting point-giving breathers, rather than polluters, the entitlement. See supra note 57 (discussing endowment effects).

114. For a discussion of the difficulties of emissions trading, see S. BREYER, supra notc 3, at 17174, 271-84 (discussing probleins includimg strategic biddmg, administration, monitoring, initial allocation of rights, and uncertainty of future prices); S. KELMAN, supra note 110; Latin, Ideal Versus Real Regulatory Effieiency: Implementation of Uniform Standards and "Fine-Tuning" Regulatory Reforms, 37 STAN. L. REV. 1267 (1985) (arguing that, in practice, an individualized approach to regulation is more mefficient than a uniform approach because of increased uncertainty, decisionmaking costs, and strategic behavior).

To its credit, the Environmental Defense Fund (EDF) has long been a strong advocate of emissions trading. See Environmentalists, Industry Disagree on Basis for Nitrogen Oxides Regulation, Daily Rep. Execs. (BNA) No. 149, at A10 (Aug. 2, 1991) (stating that the EDF has "championed" emissions trading);

115. For an especially good discussion of this and other problems, see S. BREYER, supra note 3, at 271-84.

116. See supra notes $85-91$ and aceompanying text. 
crucial. Implementation problems can in turn be solved through inarket mechanisms and "siting" policies preventing undue collection of polluters. ${ }^{117}$

These basic ideas also support an emissions trading systein in the international arena. Under such a system, some countries would pay others-in casl, retirement of debt, or new technology-to reduce emissions levels or to protect biological diversity. In the frequent cases in which pollution crosses national boundaries, a trading system would produce more efficient reduction techniques and would also be more equitable than an approach that would require all countries to use the same control technology.

b. Taxation. The simplest reform strategy to control pesticides and other toxic substances would be to impose a tax on their use. Through this simgle step, people would decrease their use of pesticides. This strategy would encourage the use of alternative methods of pest control, mcluding those that do not rely on cliemicals. ${ }^{118}$ Perliaps funds collected from a pesticide tax could be allocated to help farmers use biological techniques efficiently.

Taxation can also be used to decrease automobile emissions. Instead of existing regulations that impose technological requirements on new cars $^{119}$ (whicl1 are often ineffective and difficult to monitor, and which create incentives to keep old cars on the road longer ${ }^{120}$ ), Congress should adopt broad plans to reduce dependence on the automobile. Strategies might mclude "old car" taxes or increased gasoline taxes. ${ }^{121}$

Increased gasoline taxes are an especially promismg strategy because they would promote energy conservation and imdependence while effectively combatting pollution. The gasoline tax in the Umited States is currently the lowest of any imdustrialized nation; it should be raised to ensure that gasoline users imternalize the environinental costs of their ac-

117. See generally Ackerman \& Stewart, supra note 86 .

118. For example, pest control strategies involving biological techniques have proved quite successful, and inexpensive in the long run as well. See B. CoMMONER, supra note 99, at 97-98.

119. See 42 U.S.C. $\S 7521$ (1988).

120. See R. Crandall, H. Gruenspecht, T. KeEler \& L. LAve, supra note 74, at 89-91 (regulation of emission control by performance standards for new sources are ineffective, resulting in increased demand for older vehicles and enforcement problems, because industries find the program easy to subvert given the infrequency of enforcement audits).

121. See Postel \& Flavin, Reshaping the Global Economy, in ThE STATE of THE WORLD 1991 at 171, 181-88 (L. Brown ed. 1991) (advocating the institution of "green taxes" and the restructuring of government incentives to reduce pollution and place an emphasis on "sustainable progress" as opposed to maximum economic growth). 
tivity. ${ }^{122}$ Such an approach would avoid several problems of the prevailing command-and-control method of controlling automobile pollution, mcluding imefficiency, a tendency to increase old car retention rates, and technological breakdown by specified antipollution devices. ${ }^{123}$

It is not sufficient to respond that gasoline taxes (or any other efforts that require actors to internalize the social costs of their harmful activity) would be "regressive," in the sense that the poor would feel their effects more sharply than the well-to-do. To be sure, any effort to use incentives is likely to be harder on those with few resources than on those with many. Indeed, any strategy to control many social problems will increase prices, and thus hit the poor especially hard. For at least three reasons, however, a system requiring an activity to reflect its true social costs should not be deemed illegitimate merely because it has more severe consequences for the poor.

First, well-functioning markets ensure that the prices of products reflect their social costs. Any pricing system, in any market, works against the poor in the sense that poor people are less able to pay for commodities than are those with greater resources. The wealthy will always be able to afford the prices set by the market for products-froin soap to computers to food-more easily than the poor. But when society determines that certain commodities should be available to the poor, and that the market prices of those commodities are too high for some people, the sensible solution is to reduce poverty or to grant governinent subsidies to people who are unable to afford those comınodities. It is not to make ad hoc adjustments to the pricing system by allowing government to fix prices and thus to keep prices artificially low. Governınent price-fixing will be inefficient and will produce a range of unintended harmful consequences, mcluding misallocation of supply and demand, leading to scarcity. ${ }^{124}$

When government refuses to ensure that products (like energy) reflect their environmental costs, the result is analytically the same as a government decision to fix prices. Such a refusal will lower the price of the resulting products, and some poor people will always benefit froin lower prices. But such a result is hardly a desirable approach to the problem of poverty, any more than an across-the-board, governmentally

122. See id. at 182-85. Determination of the amount of the tax of course poses difficulties. The relevant inquiry requires more than purely scientific calculations; it must involve judgments of social values as well, for there is of course no value-free way to ascertain the damage done by pollution.

123. See R. Crandall, H. Gruenspecht, T. KeEleR \& L. LAVE, supra note 73, at 89-90.

124. For example, government price controls contributed to the energy crisis of the early 1970s. See generally S. BREYER, supra note 3, at 64-68 (arguing that government-imposed price controls lead to shortages by keeping prices artificially low and allowing few upward price adjustments as the seller's costs inevitably increase over time). 
mandated ten percent reduction in the price of (say) automobiles and soap, which it rather resembles.

Second, the pollution tax is no more regressive than command-andcontrol strategies. Suppose, for example, that government continues to require expensive, statutorily specified antipollution devices for new cars. This system also imposes costs that will ultimately be reflected in prices-but in a more arbitrary, less predictable, and less visible way than a direct tax. ${ }^{125}$ Despite the common assumption that technological requirements impose costs on industry and not on consuners, industry will usually raise prices and thus pass costs on to consumers. The view that regulatory requirements are directed at companies rather than consumers is thus a highly artificial misunderstanding of regulation, one that iguores its real-world effects.

Third, and finally, a failure to require enterprises to bear the full environinental and social costs of their activities is not a sensible redistribution strategy. The class of beneficiaries simply does not correspond to the category of needy people. A government subsidy that lowers the cost of sources of carbon-dioxide and other greenhouse gases benefits people who use those harmful substances. These beneficiaries are not the people who can legitimately claim government support. For all these reasons, the apparently regressive ${ }^{126}$ character of any "pollution tax" does not count as a reason against its use.

c. Deposits. Deposits might be especially useful in the regulation of solid and hazardous waste. The current waste control regulations ensure that neither producers nor consumers of waste materials pay disposal costs; ${ }^{127}$ neither has an incentive to reduce waste. A deposit system, however, would inake it inore expensive to dispose of substances in landfills or in the oceans, by requiring that those who handle waste pay a deposit, refundable in whole or in part upon a showing of safe disposal

125. The costs of command-and-control strategies are more arbitrary because they are less connected with antipollution goals. We cannot know whether antipollution technology achieves pollution benefits commensurate with the costs, because the technology will invariably be placed on all new cars, regardless of the amount of pollution in the relevant area or the consequences for old cars.

126. Even the term "regressive tax" is misleading in light of the fact that the goal of pollution taxes is to require that goods reflect their true social costs. A regulatory system that accomplishes this goal should not be characterized as a "regressive tax" system.

127. The Resource Conservation and Recovery Act of 1976 (RCRA), Pub. L. No. 94-580, 90 Stat. 2795 (codified as amended in scattered sections of 42 U.S.C.), focuses primarily on waste treatment rather than waste minimization. For an especially helpful discussion of possible improvements, see Mennell, Beyond the Throwaway Society: An Incentive Approach to Regulating Municipal Solid Waste, 17 EcoloGY L.Q. 655 (1990) (arguing that current policies toward waste disposal should be altered to force consumers and manufacturers to consider the true social costs of waste disposal; possible options include curbside charges based on weight or volume, or a system in which the purchaser pays the disposal costs at the point of sale). 
and recycling. The government would thus encourage recycling and discourage the accumulation of solid and hazardous waste.

2. Market-Based Incentives for Occupational Safety and Health. Market-based incentives should also form the basis for the regulation of occupational safety and health. Congress or OSHA might rely far more on einployers' actual performance in reducing deaths and injury and far less on their compliance witl rigid and unrealistic national standards for workplace design. A tax on einployers for inaintaining dangerous conditions, greater reliance on workers' compensation and on disclosure of risks to workers, and more active bargaining and employee involvement in the process of monitoring workplace safety, are all promising techniques. ${ }^{128}$

Strategies of this general sort can also promote democratic goals. A tax or fine systein ensures that soineone in a position of public accountability will decide on appropriate levels of risk. Disclosure strategies allow workers to learn about risks and risk levels, and to take action accordingly. ${ }^{129}$ In the workplace, such strategies enlist einployee support in reducing occupational risks, and in a lighly decentralized inanner. ${ }^{130}$ This step would greatly improve the current system, which relies on the national dictation of risk levels. ${ }^{131}$ Nationalized risk decisionmaking prevents einployees from becoming involved in the choice ainong risk levels, salaries, and other goals, ${ }^{132}$ and it is particularly vulnerable to interestgroup pressures. Greater decentralization would reduce these difficulties.

A system that proinotes disclosure of occupational risks also fortifies the pohitical processes at all levels of government. Disclosure ensures

128. See P. Weiler, Governing the WorkPlace: THE Future of LABOR and EMPLOYMENT LAW 191-93 (1990) (discussing employee involvement plans (EIPs) that are designed to address a number of workers' issues, imcluding job hazards). These strategies have proven successful in other countries, including Sweden. See S. Kelman, Regulating America, Regulating SweDen: A Comparative Study of Occupational Safety and Health Policy 199-203 (1981) (legislation in the 1970s has given safety stewards greater power to force employers to comply with safety regulations; various labor-management agreenents urge manageinent to take an active part in labor-1nanageinent safety coinmittees).

129. See Einergency Plannimg and Coınınumity Right-to-Know Act, 42 U.S.C. $\S 11,044$ (1988). See also the discussion in OfFice of MANAGEMENT AND Budget, Regulatory Program of THE UNITED STATES GOVERNMENT, April 1, 1990-March 31, 1991, 26-32 (1991), and in particular the analysis of OSHA's hazard commurication standard at 28-29.

130. See Rose-Ackerman, supra note 3, at 358-60 (advocating a policy that discloses job hazard information to workers in a "clear and nontechnical" form, as well as direet regulation of the workplace by the government).

131. See 29 U.S.C. $\$ 655$ (1988).

132. Bargaining should not, however, be allowed to reduce health and safety requirements below a certain floor. See Rose-Ackerman, supra note 3, at 358-64. 
better-informed decisions, enhanced by greater public understanding of risk levels and a recognition of the inevitability of choice among competing and diverse social goods. In particular, local communities would be in a better position to decide on the appropriate mix among environmental, econoinic, employment, and other goals.

Disclosure also increases flexibility, participation, and voluntariness in regulation, while decreasing informational pressures on agencies and dependence on government generally. In this respect, a shift from coinmand-and-control to incentive-based strategies lolds out enonnous promise.

3. Market-Based Incentives in Other Areas. These recommendations apply in areas outside of environmental and occupational safety and health regulation. In labor law, for example, greater encouragenient of collective bargaining and worker organization (though perhaps througli less traditional forms than ordinary unionization ${ }^{133}$ ) should replace centralized national prescriptions.

These recommendations could also be employed to regulate broadcasting. The considerations outlined in Part II suggest reasons to be skeptical of unrestricted markets in broadcasting. ${ }^{134}$ In their capacity as pohtical participants, inembers of the public appear to liave aspirational goals that conflict with market outconies in this area. The regulatory status quo produces a nnmber of problenis; inost notably an accelerating "race to the bottoin" in terms of the quality of programming. Television and radio tend to be excessively influenced by the concerns of advertisers, rarely deal with serious problems, and are frequently violent, sensationalistic, prurient, dehumanizing, and banal. ${ }^{135}$ Inevitably, such prograinming will have effects on the information, behefs, and even desires of histeners and viewers. Indeed, these effects might well be understood as externalities. In these circuinstances, a regulatory response nay be justified.

That response need not, however, take the form of a rigid and to some degree ineffectual "fairness doctrine."136 Instead of imposing uni-

133. See generally P. WEILER, supra note 128, at 187-224 (1990) (discussing possible future options for worker participation).

134. See Sunstein, supra note 11, at 28-29; supra text accompanying notes 54-61.

135. For references, see Sunstein, Free Speech Now, U. CHI. L. REv. (forthcoming 1992).

136. That doctrine required attention to public issues and an opportunity to speak for opposing views. See L. Powe, American Broadcasting and the First Amendment (1987). To be sure, first amendment questions lurk behind any effort to regulate broadcasting. I do not discuss those issues here, although a conception of the first amendment that would argue for, rather than against, regulatory efforts seems entirely plausible. See Red Lion Broadcasting Co. v. FCC, 395 U.S. 367,390 (1969) (viewers' and listeners' first amendment rights demand that the marketplace of idcas 
form obligations, the licensing agency might award extra "points" to applicants who provide high-quality broadcasting or who attend to public issues-even if those applicants were less coinpetitive in the inarketplace. This type of "point" strategy would not dictate outcoines, but it would create market-like incentives to engage in desirable behavior. Alternatively, government could require that ordinary broadcasters give a specified percentage of their profits either to public broadcasting or to private companies that are willing to sacrifice some of their advertising revenues and audience to provide higher-quahity fare. This system would introduce some of the virtues of environmental emissions trading systems into broadcasting regulation.

\section{LESSONS FOR THE JUDICIARY}

The suggestions made thus far are primcipally directed at legislators and administrators. As I have indicated, a focus on substance requires a movement away from the traditional preoccupation with the judiciary to a focus on congressional and bureaucratic processes. These remain illunderstood despite the fact that they have far inore important roles in government regulation. ${ }^{137}$ Concern with regulatory substance does, however, have consequences for judicial review as well. Concentration on regulatory results inay require an adjustment in statutory interpretation and in decisions about which regulatory approaches are "arbitrary" within the meaning of the Administrative Procedure Act (APA). ${ }^{138}$ I offer a few suggestions here. ${ }^{139}$

Statutory imterpretation usually involves an ascertainment of ineaning through an examination of the statutory text, structure, and history. ${ }^{140}$ When the meaning of a statute is otherwise clear, courts should not rely on any substantive ideas about the regulatory state to subvert that meaning. Statutory meaning is, however, a function of interpretive principles, without which text and listory are unintelhibible. Soine of these principles are simply parts of language, soine can be traced to constitutional norms; and others are a product of judicial understandings about institutional concerns.

In easy cases, interpretive principles are so widely shared as to be invisible. For example, the Clean Air Act does not preeinpt state tort

be protected from monopolization, whether by government or by private licensee); L. BOLLINGER, IMAGES OF A FREe PRESS (1991); Sunstein, supra note 135.

137. See supra notes 1-13 and accompanyiug text.

138. 5 U.S.C. $\$ 706(2)(A)(1988)$.

139. For an more elaborate discussion, see C. SuNSTEIN, supra note *, at 111-92.

140. See Chevron U.S.A., Inc. v. Natural Resources Defense Council, Inc., 467 U.S. 832 (1984) (examiming these sources). 
law-not because of any language in the text itself, but because of agreed-upon conventions about the limited preeinptive effect of federal statutes. ${ }^{141}$ In more difficult cases, however, interpretive principles are inentioned explicitly. Thus, for example, courts use canons of construction to construe statutes so as to avoid constitutional doubts, ${ }^{142}$ and to favor Indian tribes. ${ }^{143}$ These and inany other principles give meaning to statutory silences and help resolve cases otherwise in equipoise.

Interpretive principles are not static. They change over time, with new understandings about which principles are better adapted to contemporary government. An understanding of regulatory aspiration and failure could well form the basis of new primciples of statutory interpretation. Indeed, such understandings play a large role in existing doctrine, whether exphicitly or imphicitly. ${ }^{144}$ Courts might ultimately develop a set of principles attuned to the often-salutary goals of regulatory programs and to the ways that these programs break down in practice.

For example, courts might be encouraged to take into account the sometimes counterintuitive systemic effects of government regulation. ${ }^{145}$ The consequences of different strategies are often relevant both to statutory ineaning and to the question of "arbitrariness" within the ineaning of the APA. In addition, courts might better understand the paradoxes of the regulatory state, and consider, for example, the possibility that regulating new risks can perpetuate old risks, that especially severe regu-

141. See, e.g., Mansell v. Mansell, 490 U.S. 581, 587-88 (1989) (in areas of traditional state law preeminence, such as domestic relations, a federal law will not be read so as to preempt state law unless preemption is "positively required"); Puerto Rico Dep't of Consumer Affairs v. Isla Petroleum Corp., 485 U.S. 495, 499-501 (1988) (the Court looks for a "clear and manifest" purpose by Congress to supersede existing state law, before preemption by a federal statute is allowed); Hillsborough County v. Automated Medical Laboratories, 471 U.S. 707, 715-16 (1985) (where local health and safety regulations are concerned, there is a presumption that the local regulations coexist with similar federal regulations).

142. See, eg., NLRB v. Catholic Bishop, 440 U.S. 490, 507 (1979) (refusing to construe National Labor Relations Act to require resolution of difficult cases under first amendment rehigion clauses); Kent v. Dulles, 357 U.S. 116, 129 (1958) (narrowly construing the broad power delegated to the Secretary of State to issue passports because the right of a citizen to travel abroad is an important hiberty and cannot be deprived without due process of law).

143. See Montana v. Blackfeet Tribe of Indians, 471 U.S. 759, 764-66 (1985) (Indian tribes occupy a unique position in the Umited States because of the tribes' continued sovereiguty; as a corollary of this, the Court will construe ambiguous statutes in their favor); Three Affiliated Tribes v. Wold Eng'g, 467 U.S. 138, 149 (1984) (when interpreting statutes that benefit the Indian tribes, it is a settled rule that any doubts should be construed in favor of the Indians).

144. See C. SunSTEIN, supra note *, at 111-59 (attacking many accepted principles of statutory construction and proposing an alternative approach to statutory interpretation); Sunstein, supra note 80 , at $434-40$ (discussing how judges often look at the consequences of their decisions, even if not expressly called upon to do so by the statute in question).

145. See Sierra Club v. Costle, 657 F.2d 298, 329-32 (D.C. Cir. 1981) (discussing congressional desire that regulatory standards not worsen existing problems in upholding EPA's authority to analyze the likely impacts of new standards in setting standards). 
lation can produce underregulation, and that requirements of best available technology can retard technological development. ${ }^{146}$ These paradoxes bear on a number of issues in hitigation. ${ }^{147}$

Other principles might be derived from considerations of regulatory goals and failures. To allow de minimis exemptions from regulatory requirements would do much more good than harm. ${ }^{148}$ The failure to permit such exemptions may cause inefficiency and produce risks, not benefits, to health and safety. In most cases, courts should assume that Congress wants at least some form of balancing of the various effects of regulatory statutes. ${ }^{149}$ Statutes that forbid balancing are usually underenforced or have unanticipated, but serious, adverse consequences. Courts should also construe statutes generously on behalf of disadvantaged groups, which, by definition, face systematic obstacles in the implementation process. 150

To say this is not to say that such imterpretive principles should overcoine unambiguous statutory text and history. But a better understanding of regulatory substance will inevitably affect the practice of judicial review in difficult cases.

\section{CONCLUSION}

The basic coinmitinents of conteinporary administrative law find their source in the hiberal republicamisin of the founding generation and

146. See supra notes 77-84 and accompanying text.

147. See International Union v. OSHA, 938 F.2d 1310, 1326-27 (D.C. Cir. 1991) (Williams, J. concurring); Sunstein, supra note 77, at 413-29.

148. See C. Sunstein, supra note *, at 198-99. For cases to this effect, see Bowen v. Yuckert, 482 U.S. 137 (1987) (finding that legislation that required consideration of all impairments in determining whether Social Security disability applicant could be eligible for benefits supported regulations that denied consideration of such impairments when assessing severity of disability); Alabama Power Co. v. Costle, 636 F.2d 323, 356-61 (D.C. Cir. 1979) (EPA may allow exemptions from clear statutory regulatory language for reasons of administrative necessity or where the resulting harm is de minimis); Monsanto Co. v. Keunedy, 613 F.2d 947, $955-56$ (D.C. Cir. 1979) (under the federal Food, Drug, and Cosmetic Act, the FDA has the power to label any substance as a "food additive" if even minute amounts of the substance enter a food; in practice, however, the FDA can find such additive amounts "insignificant" and not worthy of FDA regulation).

149. See Industrial Union Dep't, AFL-CIO v. American Petroleun Institute, 448 U.S. 607, 64452 (1980) (striking down an occupational health and safety standard promulgated by the Secretary of Labor because the Secretary did not make a threshold finding that a significant risk to workers existed); Natural Resources Defense Council, Inc. v. Thomas, 824 F.2d 1146, 1152-54 (D.C. Cir. 1987) (congressional silence on the definition of "ample margin of safety" does not require that the EPA set a zero level of emissions for certain pollutants for which the EPA cannot determine a harmless level of enission).

150. See Sunstein, Interpreting Statutes in the Regulatory State, 103 HARv. L. REv. 407, 483-85 (1989) (arguing that disadvantaged groups should receive the benefit of the doubt when a court interprets a regulatory statute because these groups face special difficulties in bringing an enforceinent action). 
in New Deal understandings of the twentieth-century state. Those commitments call for an extensive regulatory apparatus, one that attempts simultaneously to promote economic prosperity and to protect the disadvantaged. The foundations of modern regulation are self-consciously pragmatic. When current strategies have failed, they should be changed. Existing approaches that do not address serious problems, or that produce problems of their own, should be replaced by new ones.

I have sought to provide some illustrations of the enormous opportumities we now have with which to accomplish the goals of social regulation without returning to discredited laissez-faire principles or perpetuating the rigidities and paradoxes of current programs. Above all, regulatory reform should be attuned to the incentive effects of regulatory initiatives. Having rejected markets, regulatory programs should nonetheless take advantage of market forces where these can be harnessed to promote regulatory goals. For the most part, economic and democratic goals can work together. Efforts to increase information, to promote disclosure, to produce greater decentralization, and to shift from command-and-control to incentive-based systems promise to decrease regulatory costs and increase regulatory benefits while simultaneously bringing about dramatic miprovennents in the democratic process. To this extent, the prescriptions for increasing the efficiency of regulatory programs will also serve the end of increased democratization. ${ }^{151}$

In evaluating reforms, little is to be gained by generalities that point to the frequent problems in either government regulation or in private markets. Even the question whether there should be "more" or "less" regulation tends to confuse, rather than clarify, matters. ${ }^{152}$ Questions about the existence and extent of current problems are too dependent on context to allow for global prescriptions. It is far more helpful to rely on particularized understandings of how markets and regulation are likely to break down - to learn, in short, from the past. Ultimately, the proposals suggested here would create a system unembarrassed to use government to promote democratic aspirations and economic welfare, but insistent on strategies that embody the flexibility, adaptability, productive potential, and decentralization characteristic of private markets.

More generally, the next generation of adinmistrative law should witness a large-scale shift from judicially policed administrative procedure to regulatory programs designed by legislators and bureaucrats. To be sure, the legal culture has only begun to explore the real-world conse-

151. I do not, of course, suggest that the goals of efficiency and democracy are always incompatible.

152. See Howse, Prichard \& Trebilcock, supra note 84 , at 506-09 (claiming that question is not one of size). 
quences of regulatory programs, the values and commitments that do or should underlie those programs, and alternative mechanisms to promote the goals of regulation while minimizing the risk of regulatory failure. But it miglit not be too utopian to hope that by its fiftieth anniversary in 1996, we miglit be able to start on the patli of accompanying the largely successful $\mathrm{APA}^{153}$ with another generic statute-one that holds out even more promise, and one that attends to the problem of administrative substance rather than the control of administrative discretion. ${ }^{154}$

153. 5 U.S.C. $\S \S 551-559,701-706$ (1988).

154. A large advantage of a generic statute is that it diminishes the power of interest groups over particular areas. Two Executive Orders, Exec. Ord. 12,291, 3 C.F.R. $\S 127$ (1981), reprinted in 5 U.S.C. $\$ 601$ note (1988), and Exec. Ord. 12,498, 3 C.F.R. $\$ 323$ (1985), reprinted in 5 U.S.C. $\S 601$ note (1988), which set forth substantive principles of cost-benefit analysis and cost-effectiveness, might be seen as forerunners of this sort of approach. In addition, the implementing guidelines of the Office of Management and Budget, along with the coordination of authority within that agency, are steps in the right direction. See Office of Management and Budget, Regulatory ProGRAM OF THE UNITED STATES Government, April 1, 1990-March 31, 1991 (1991). The guidelines have usefully counteraeted problems of overregulation, lack of accountability, and lack of coordination. They also make some progress in dealing with the related problems of poor incentives and inefficiency. One remaining difficulty, however, is that the guidelines do not respond to the important problem of failure to regulate. 